\title{
A multicomponent approach toward angularly fused/linear bitriazoles: A cascade Cornforth rearrangement and triazolization
}

Santhini Pulikkal Veettil, Shandev Pookkandam Parambil, Max Van Hoof, Wim Dehaen* Molecular Design and Synthesis, Department of Chemistry, KU Leuven, Celestijnenlaan 200F, Leuven B-3001, Belgium. Email:wim.dehaen@kuleuven.be

\section{Table of Contents}


1. NMR Spectra of Compounds (1a-1e, $4 a-4 r, 6 a, 7 a, 8 a)$


邹

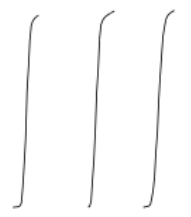

$\mathrm{O}_{2}$



${ }^{1} \mathrm{H}$ NMR $(300 \mathrm{MHz})$ spectrum of $1 \mathrm{a}$ in $\mathrm{CDCl}_{3}$

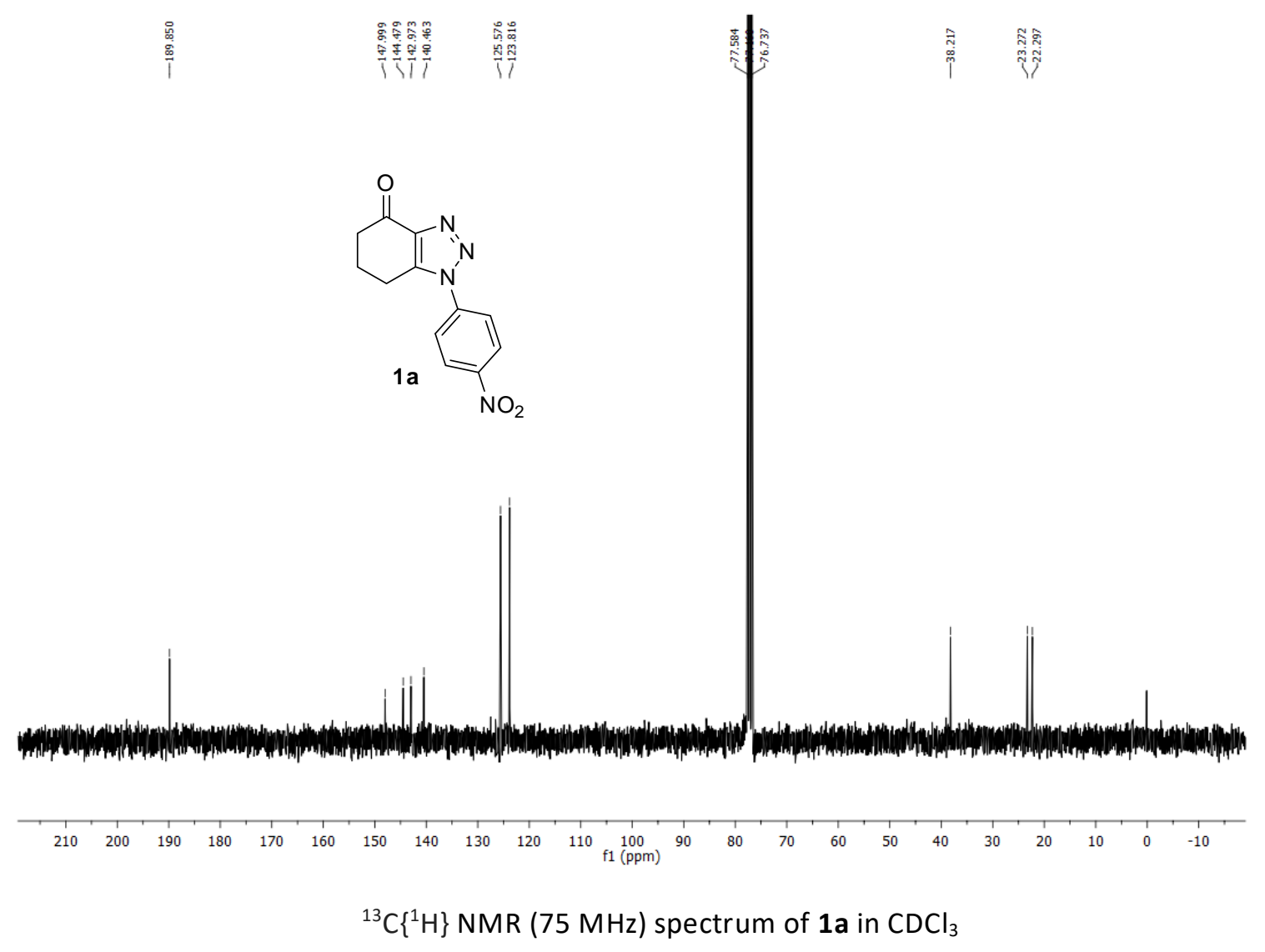




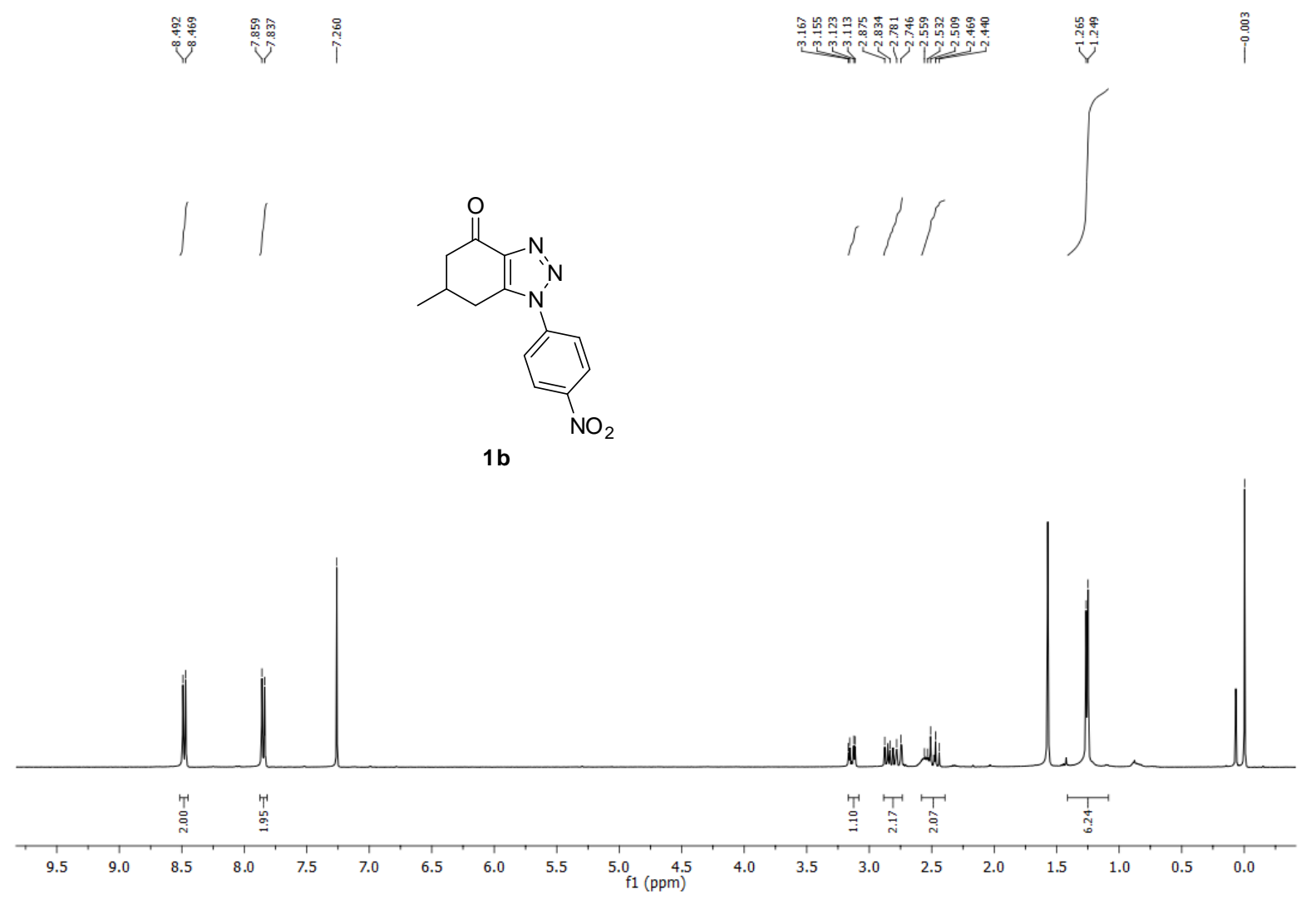

${ }^{1} \mathrm{H}$ NMR $(400 \mathrm{MHz})$ spectrum of $\mathbf{1 b}$ in $\mathrm{CDCl}_{3}$

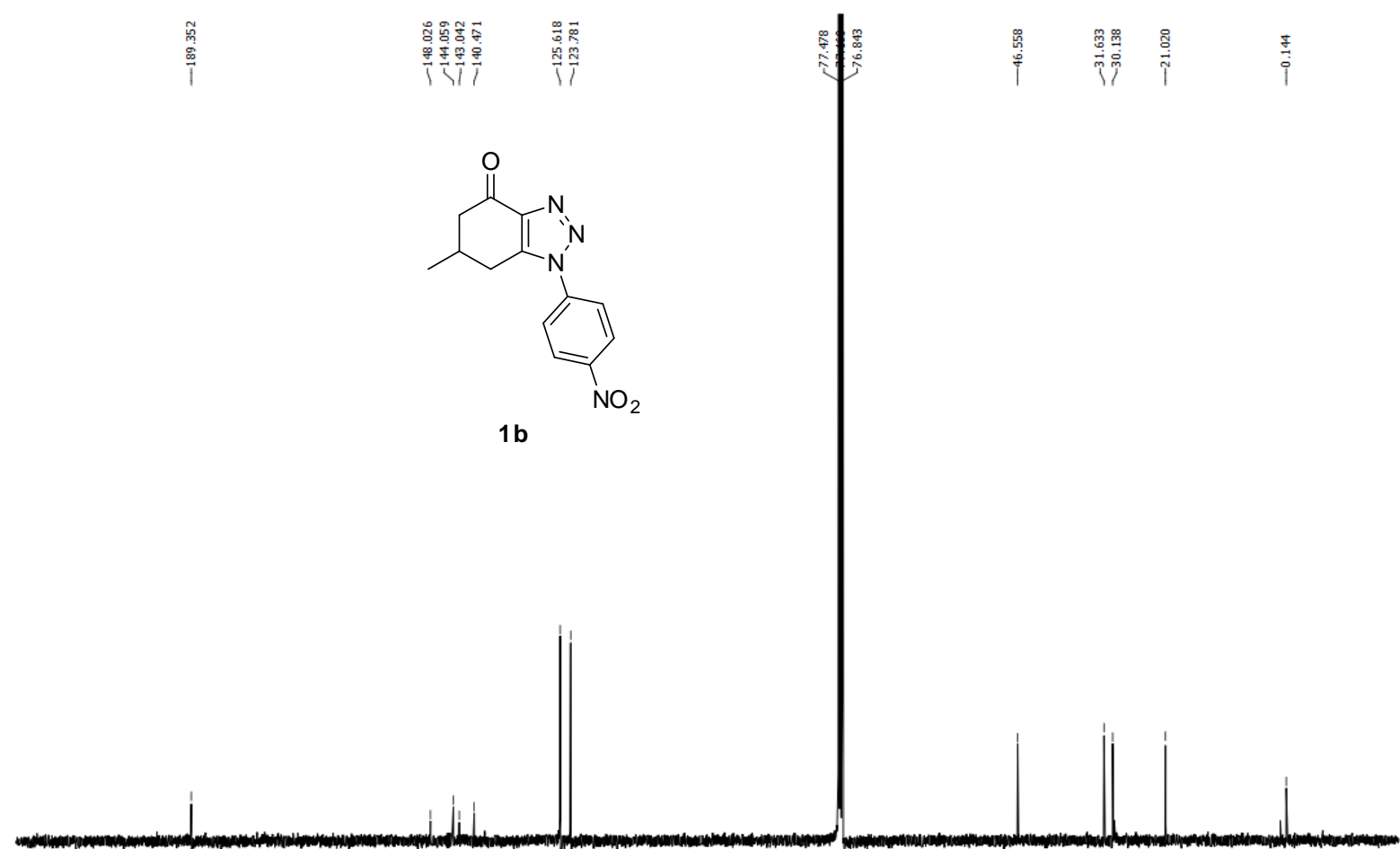

$\begin{array}{lllllllllllllllllllllllllllllll}210 & 200 & 190 & 180 & 170 & 160 & 150 & 140 & 130 & 120 & 110 & 100 & 90 & 80 & 70 & 60 & 50 & 40 & 30 & 20 & 10 & 0 & -10\end{array}$

${ }^{13} \mathrm{C}\left\{{ }^{1} \mathrm{H}\right\}$ NMR (101 MHz) spectrum of $\mathbf{1 b}$ in $\mathrm{CDCl}_{3}$ 


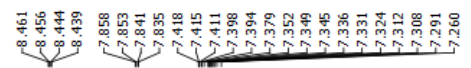

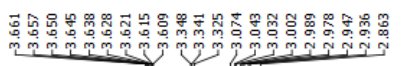

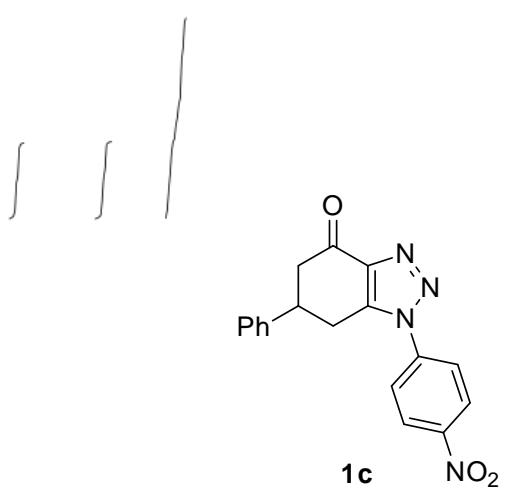

$\iiint$

$1 c$

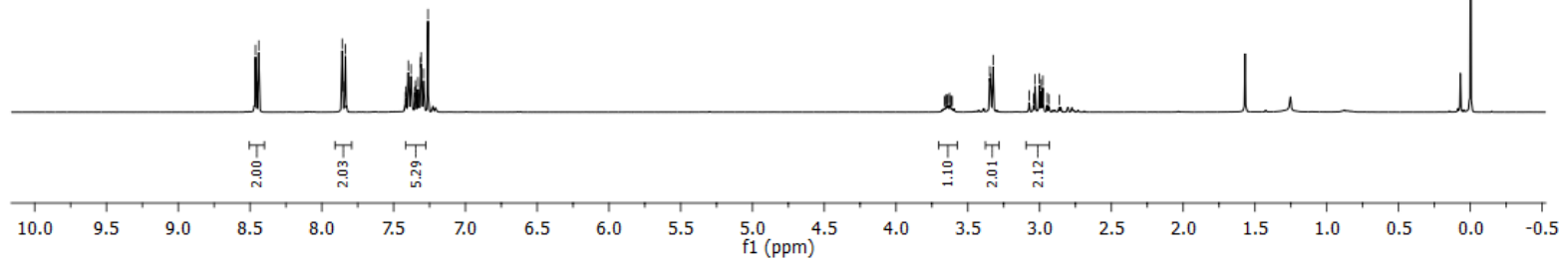

${ }^{1} \mathrm{H}$ NMR (400 MHz) spectrum of $1 \mathrm{c}$ in $\mathrm{CDCl}_{3}$

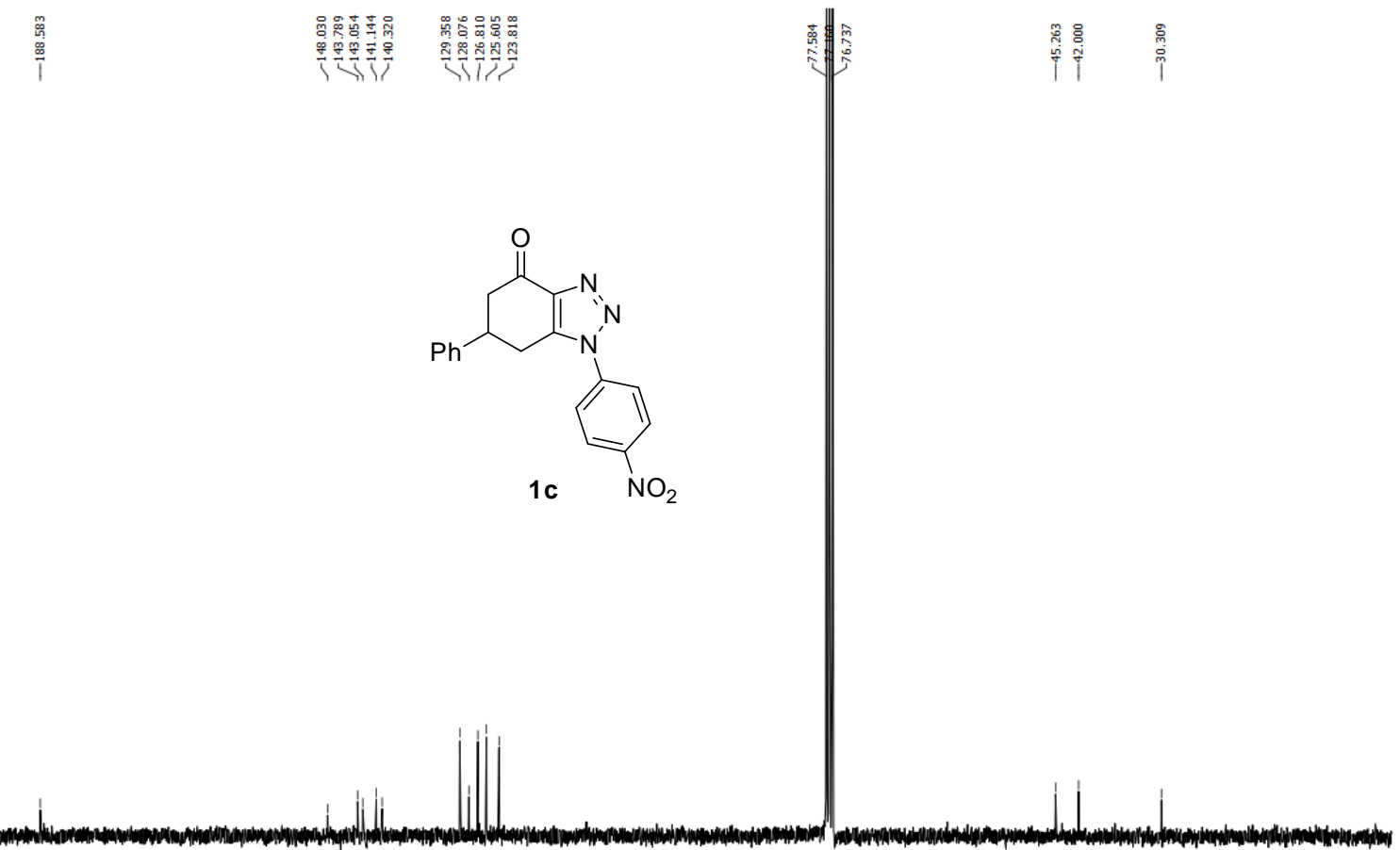

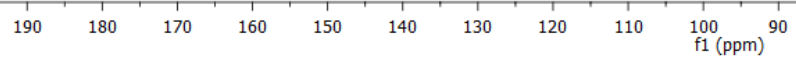

${ }^{13} \mathrm{C}\left\{{ }^{1} \mathrm{H}\right\}$ NMR (101 MHz) spectrum of $1 \mathrm{c}$ in $\mathrm{CDCl}_{3}$ 


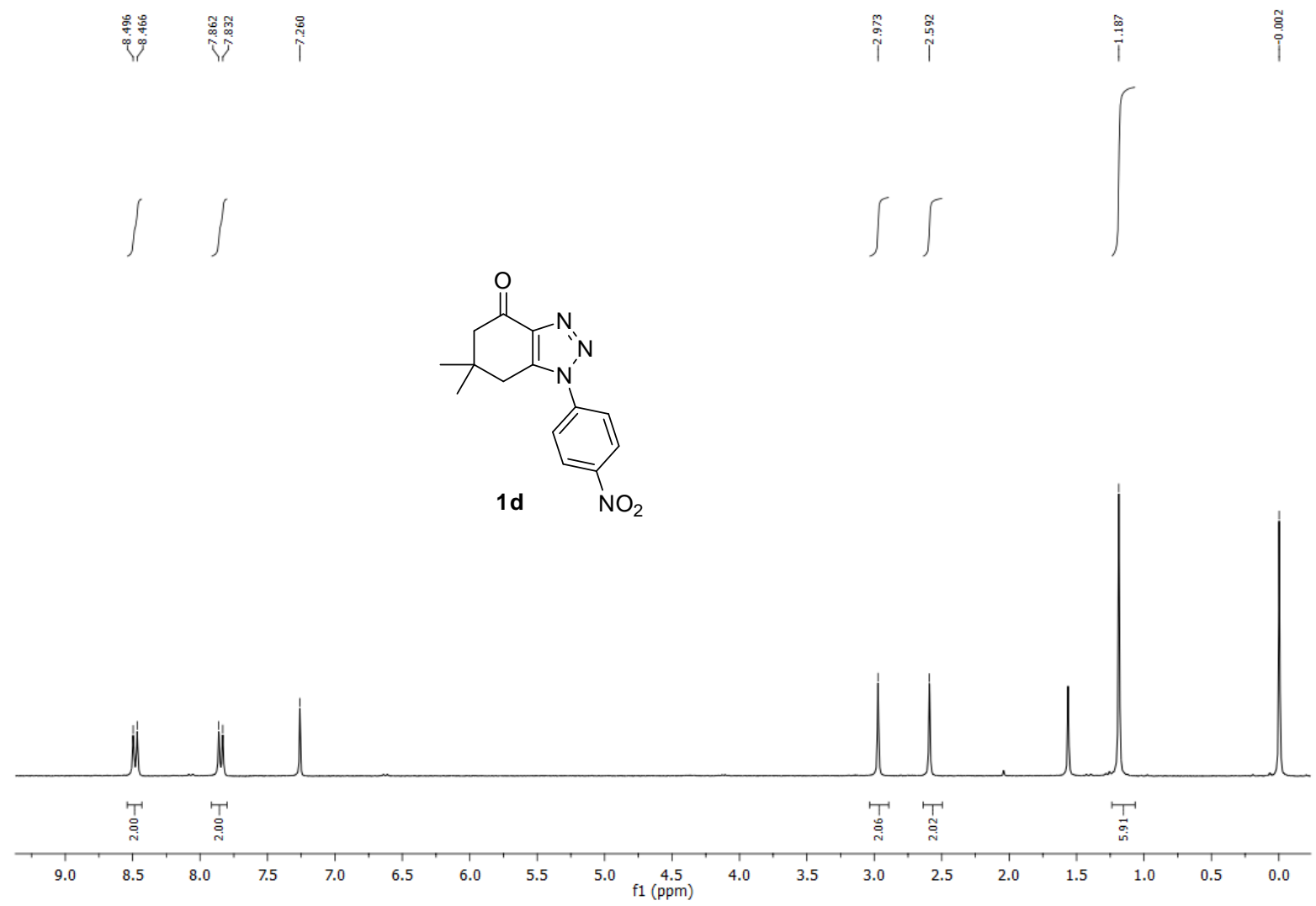

${ }^{1} \mathrm{HNMR}(400 \mathrm{MHz})$ spectrum of $\mathbf{1} \mathbf{d}$ in $\mathrm{CDCl}_{3}$



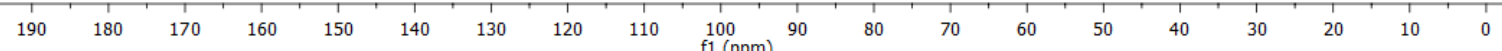

${ }^{13} \mathrm{C}\left\{{ }^{1} \mathrm{H}\right\}$ NMR (75 MHz) spectrum of $\mathbf{1 d}$ in $\mathrm{CDCl}_{3}$ 




${ }^{1} \mathrm{H}$ NMR (400 MHz) spectrum of 1 e in $\mathrm{CDCl}_{3}$
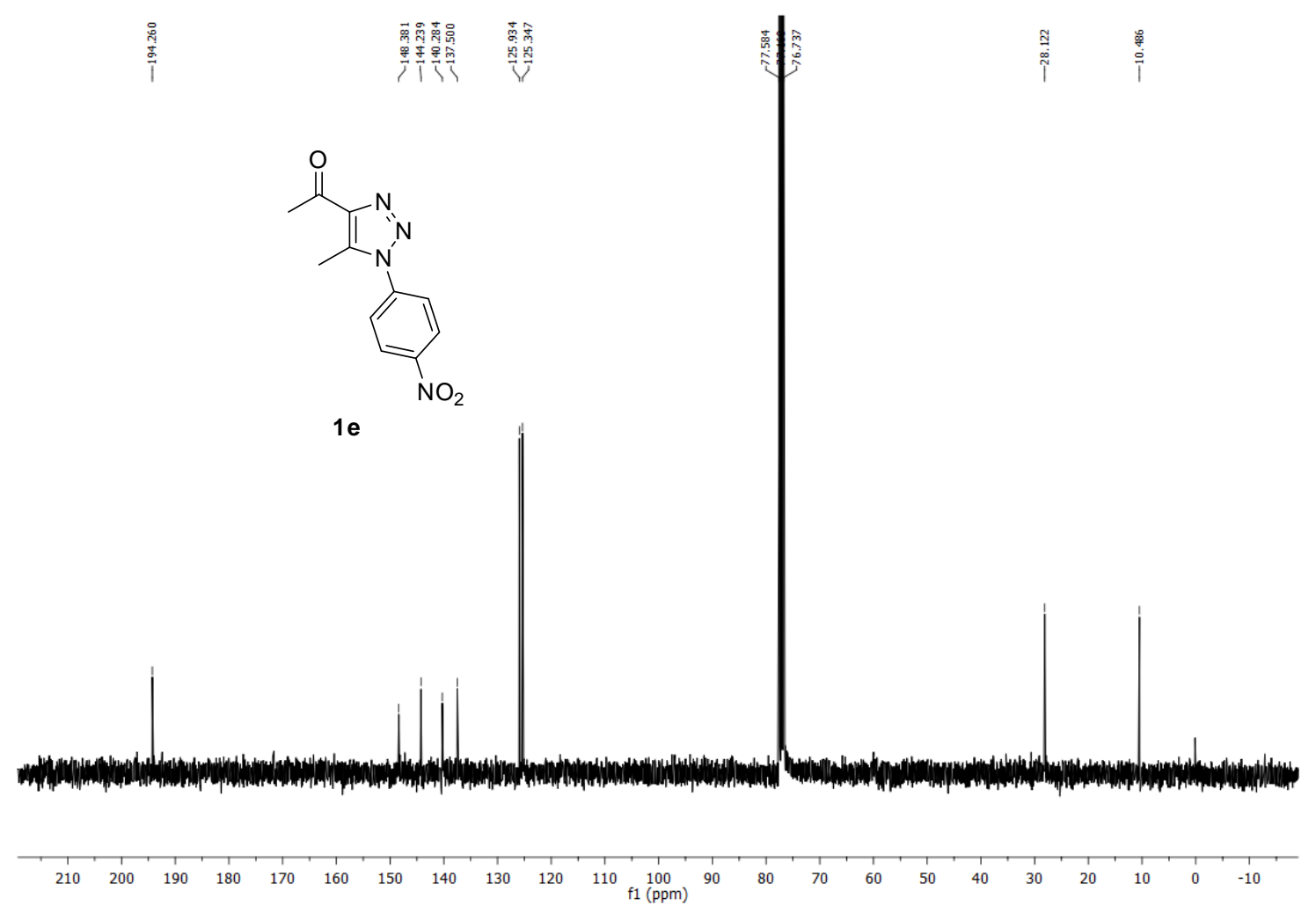

${ }^{13} \mathrm{C}\left\{{ }^{1} \mathrm{H}\right\}$ NMR (101 MHz) spectrum of $1 \mathbf{e}$ in $\mathrm{CDCl}_{3}$ 

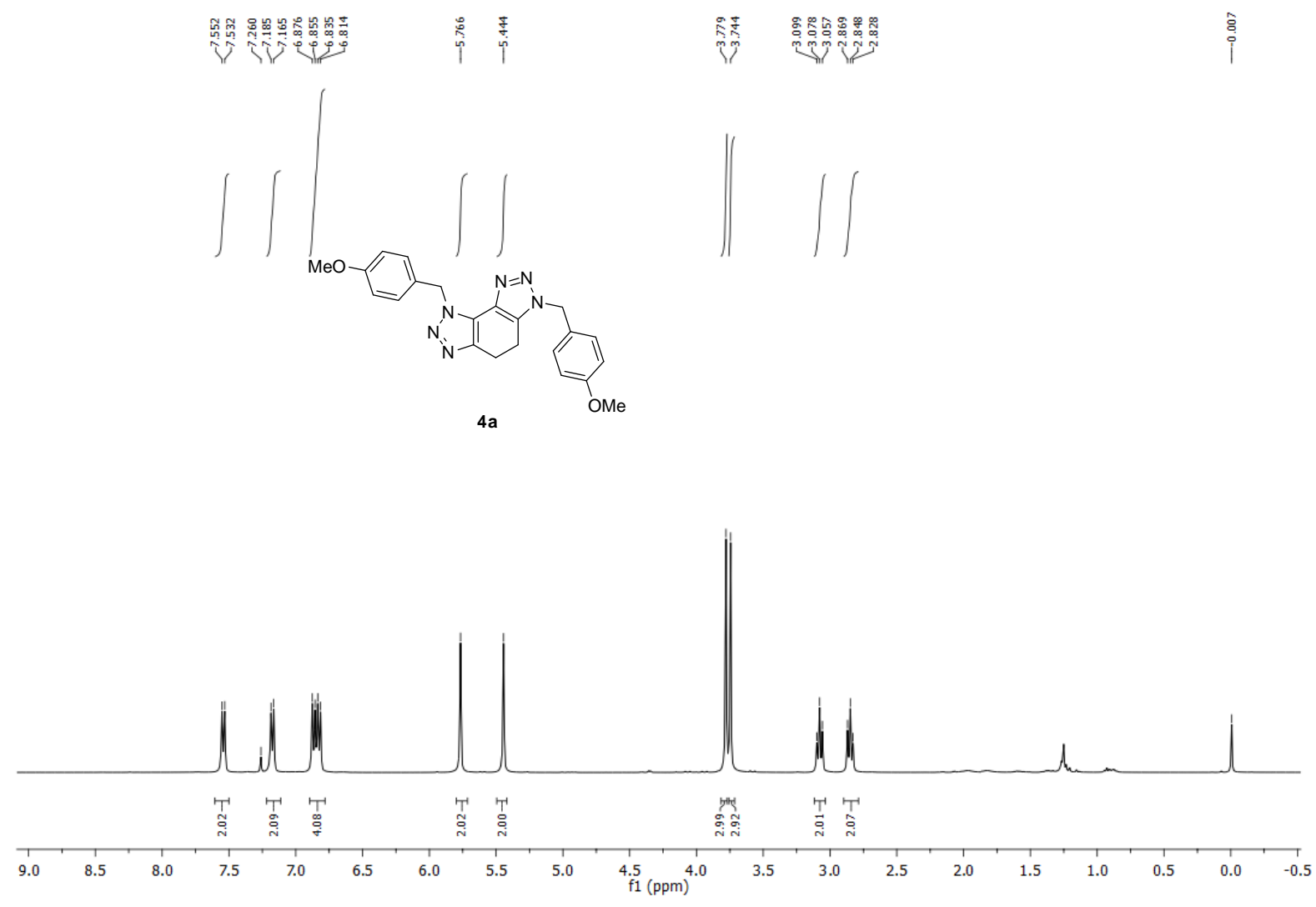

${ }^{1} \mathrm{H}$ NMR $(400 \mathrm{MHz})$ spectrum of 4 a in $\mathrm{CDCl}_{3}$

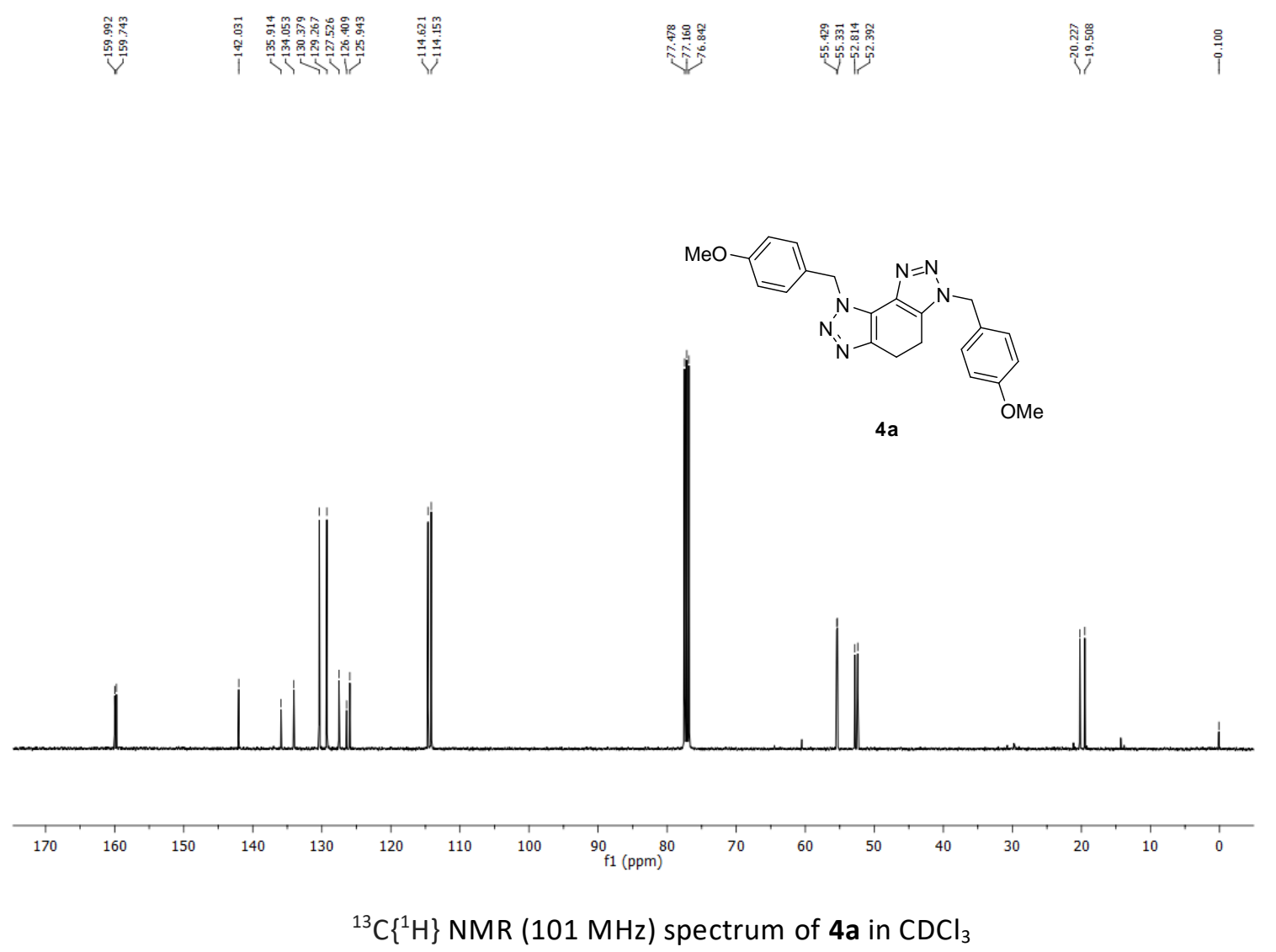




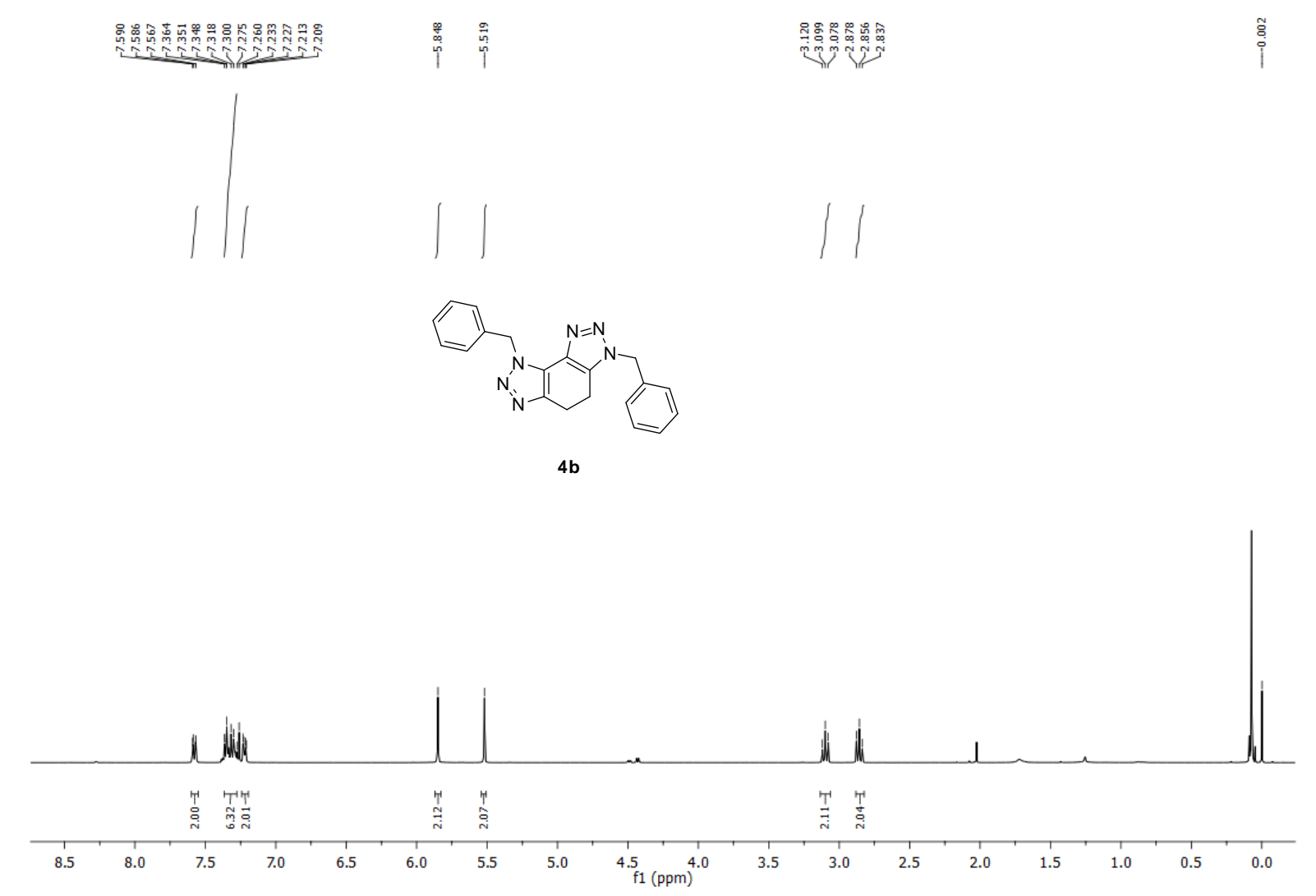

${ }^{1} \mathrm{H}$ NMR (400 MHz) spectrum of $\mathbf{4 b}$ in $\mathrm{CDCl}_{3}$

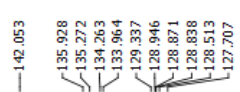

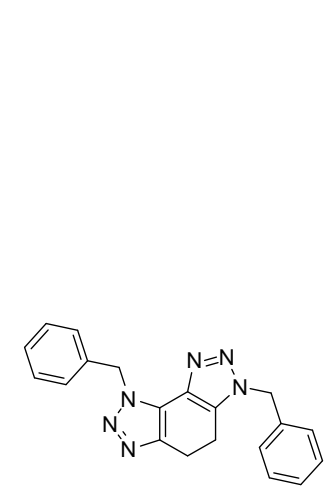



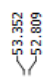

竞望

$4 b$

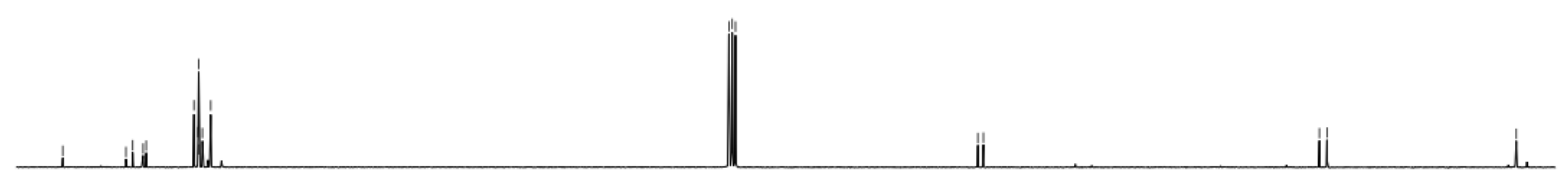

$\begin{array}{lllllllllllllllllllllllllllllllll}145 & 140 & 135 & 130 & 125 & 120 & 115 & 110 & 105 & 100 & 95 & 90 & 85 & 80 & 75 & 70 & 65 & 60 & 55 & 50 & 45 & 40 & 35 & 30 & 25 & 20 & 15 & 10 & 5 & 0\end{array}$

${ }^{13} \mathrm{C}\left\{{ }^{1} \mathrm{H}\right\}$ NMR $\left(101 \mathrm{MHz}\right.$ ) spectrum of $\mathbf{4 b}$ in $\mathrm{CDCl}_{3}$ 

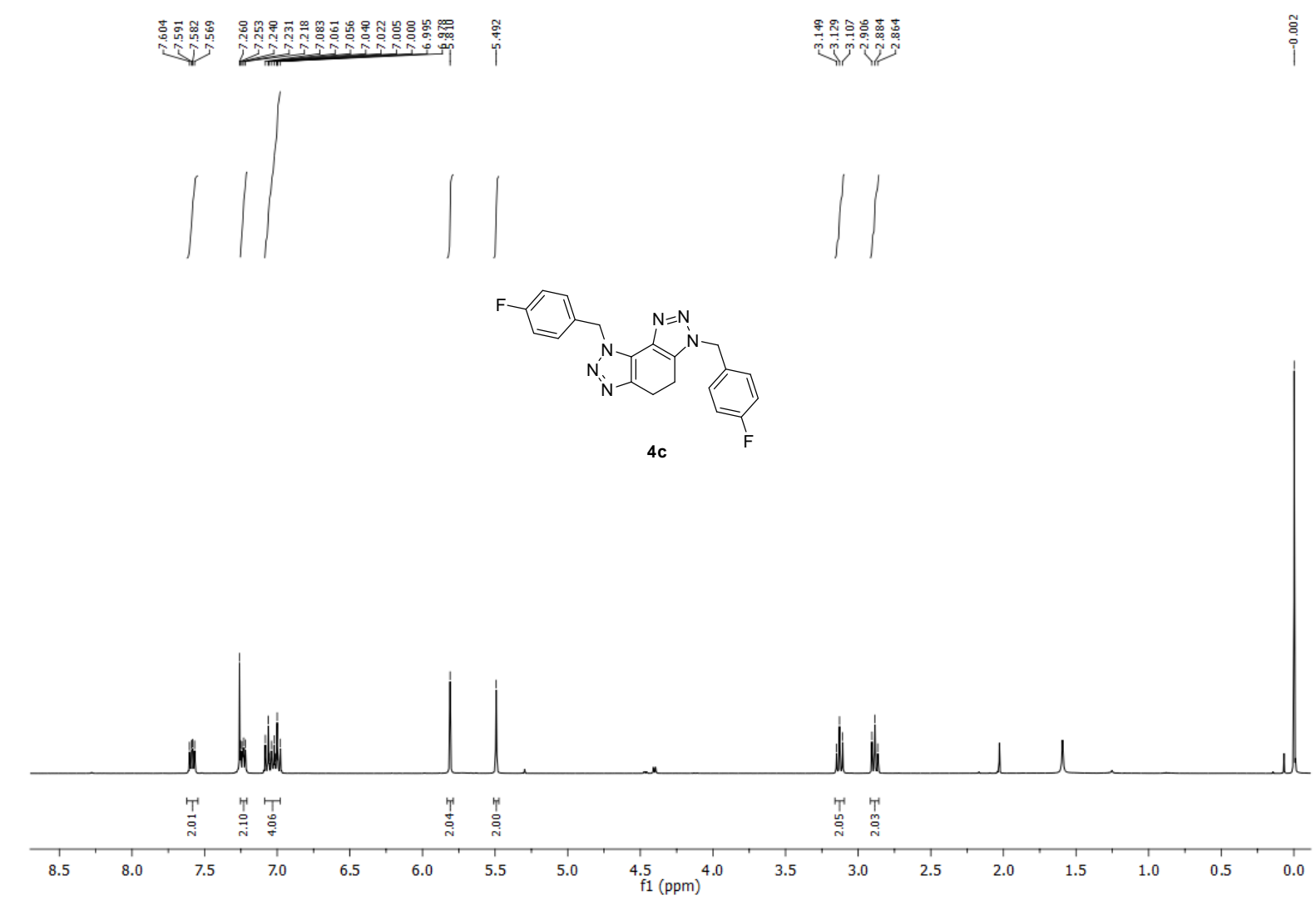

${ }^{1} \mathrm{H}$ NMR (400 MHz) spectrum of $\mathbf{4 c}$ in $\mathrm{CDCl}_{3}$

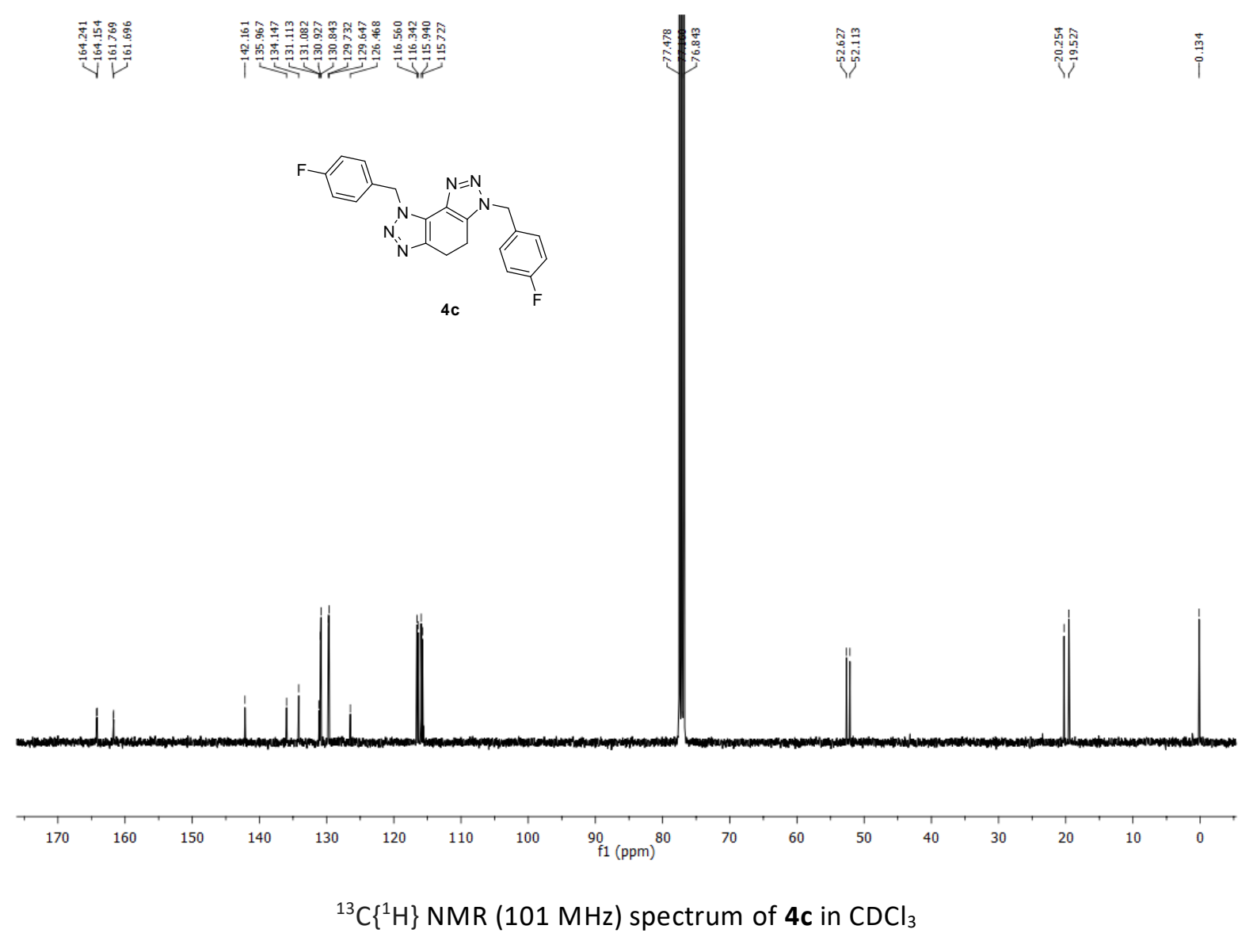




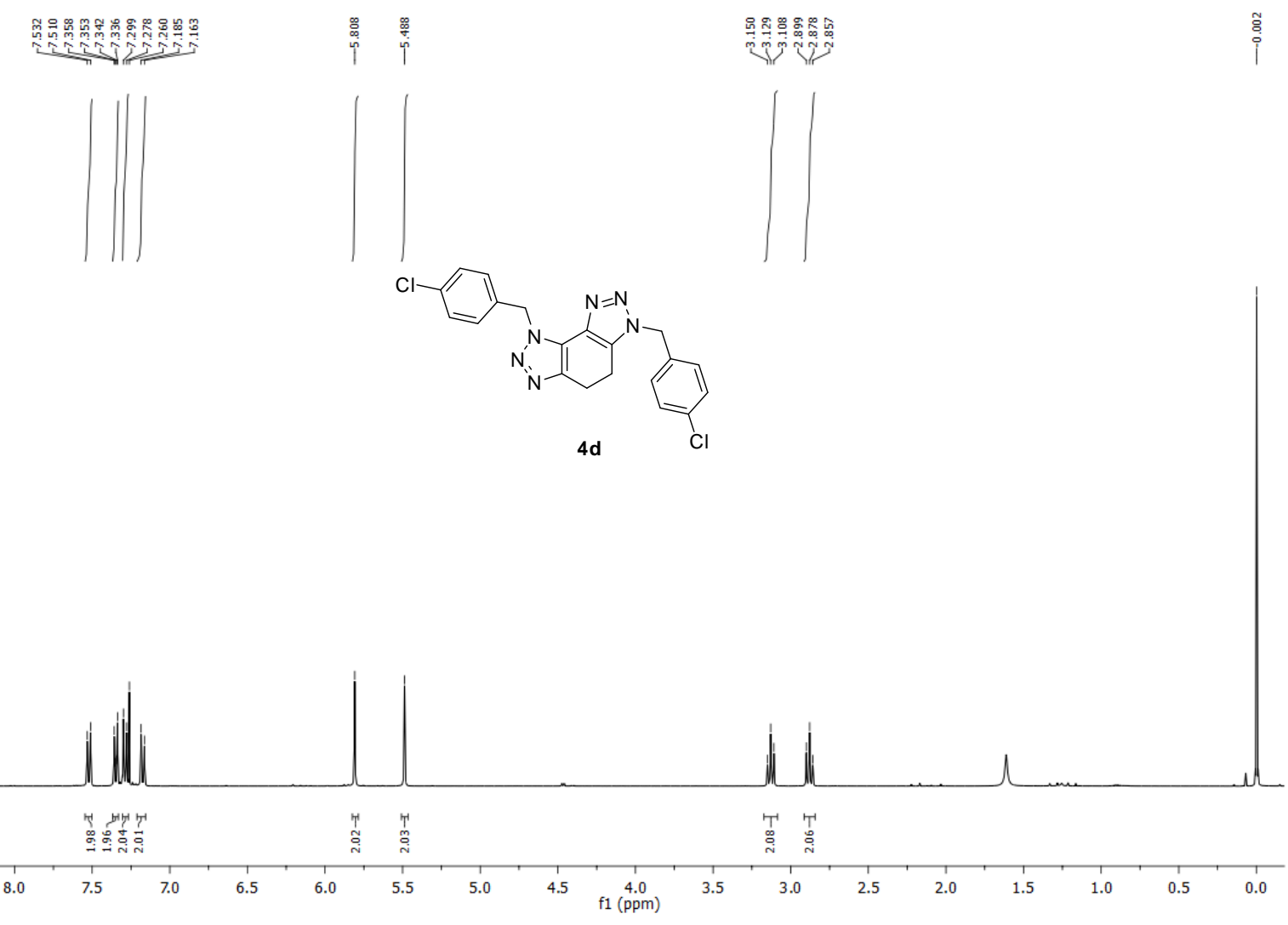

${ }^{1} \mathrm{H} \mathrm{NMR}\left(400 \mathrm{MHz}\right.$ ) spectrum of $\mathbf{4} \mathbf{d}$ in $\mathrm{CDCl}_{3}$
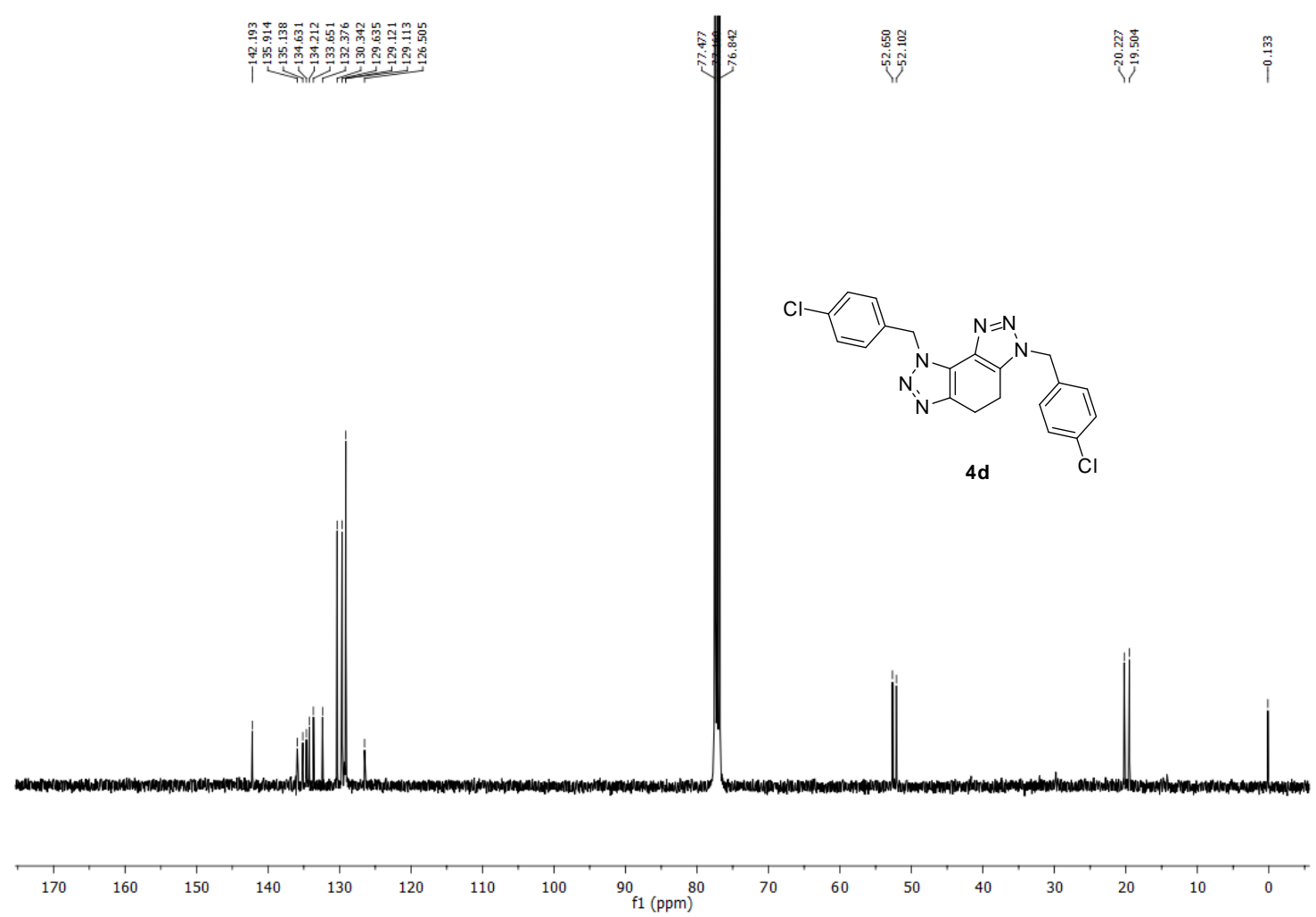

${ }^{13} \mathrm{C}\left\{{ }^{1} \mathrm{H}\right\}$ NMR (101 MHz) NMR spectrum of $\mathbf{4 d}$ in $\mathrm{CDCl}_{3}$ 


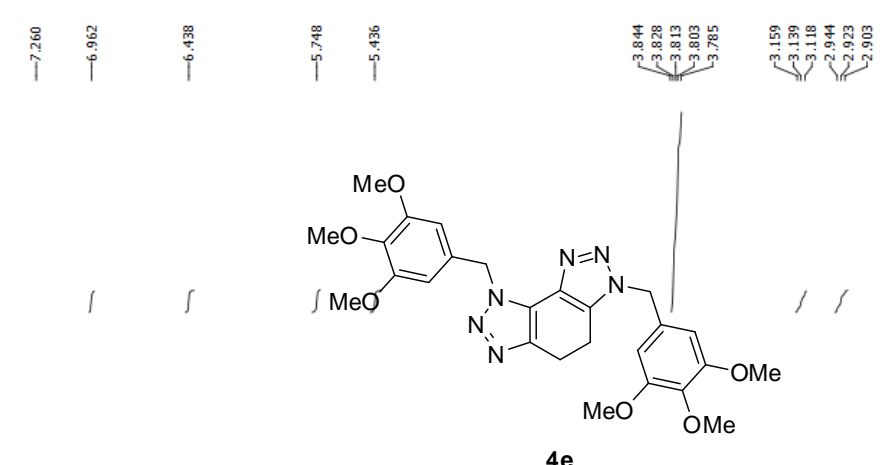

$4 e$

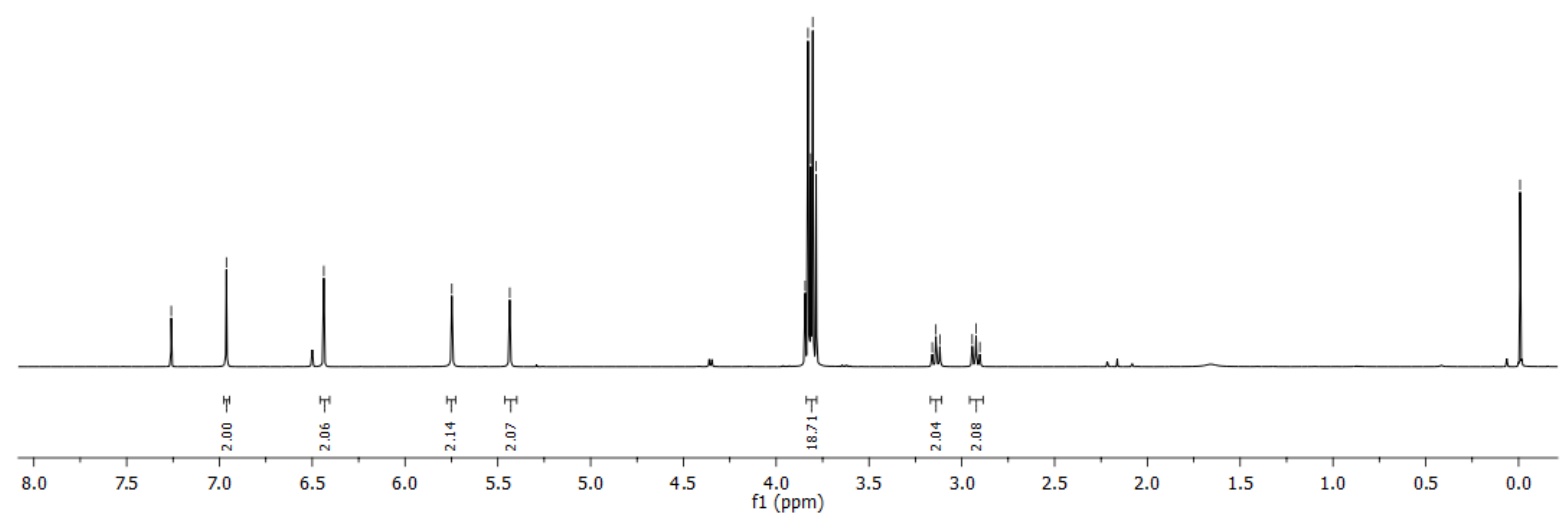

${ }^{1} \mathrm{H}$ NMR $(400 \mathrm{MHz})$ spectrum of $4 \mathbf{e}$ in $\mathrm{CDCl}_{3}$
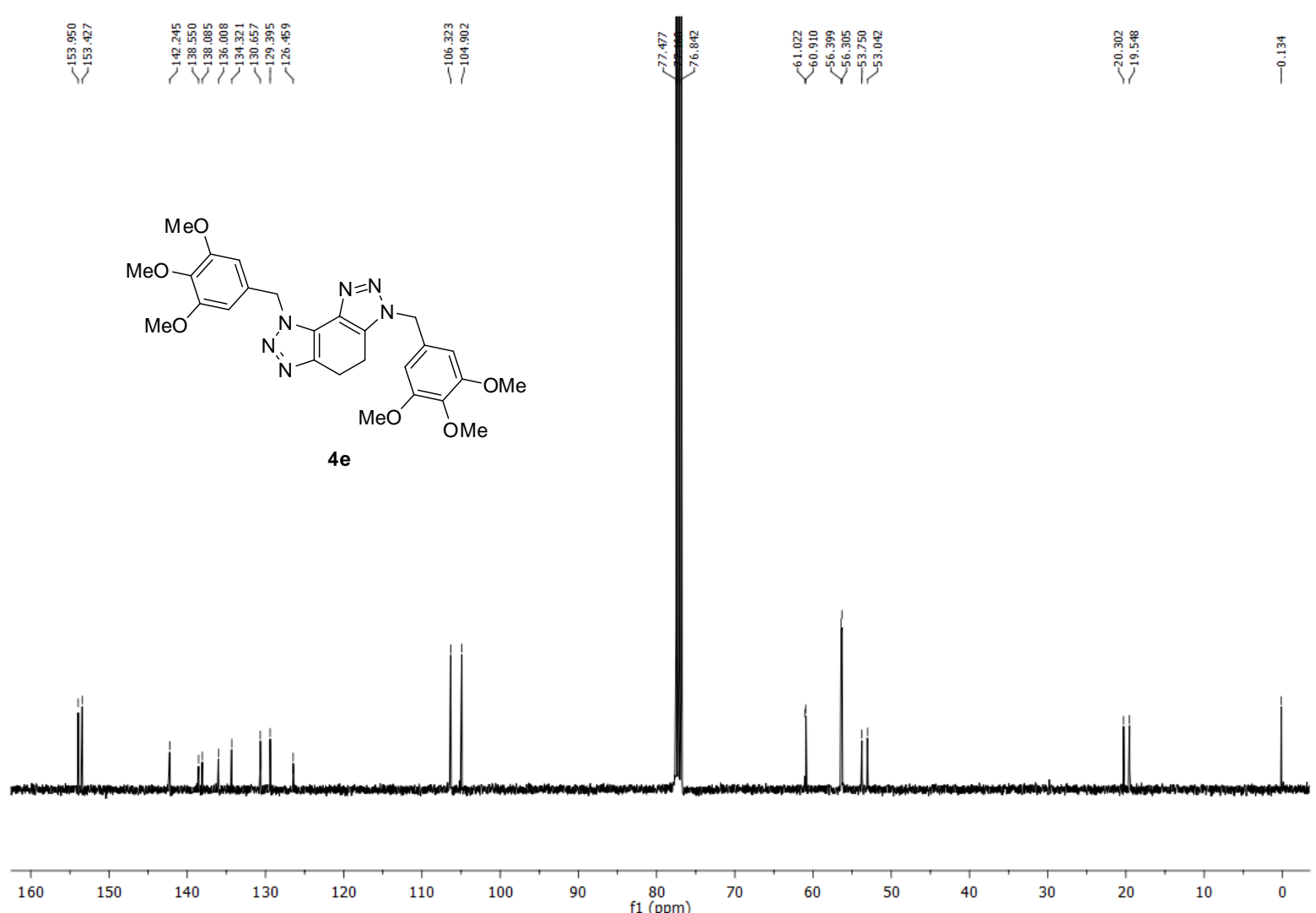

${ }^{13} \mathrm{C}\left\{{ }^{1} \mathrm{H}\right\}$ NMR (101 MHz) spectrum of $4 \mathbf{e}$ in $\mathrm{CDCl}_{3}$ 



$4 f$

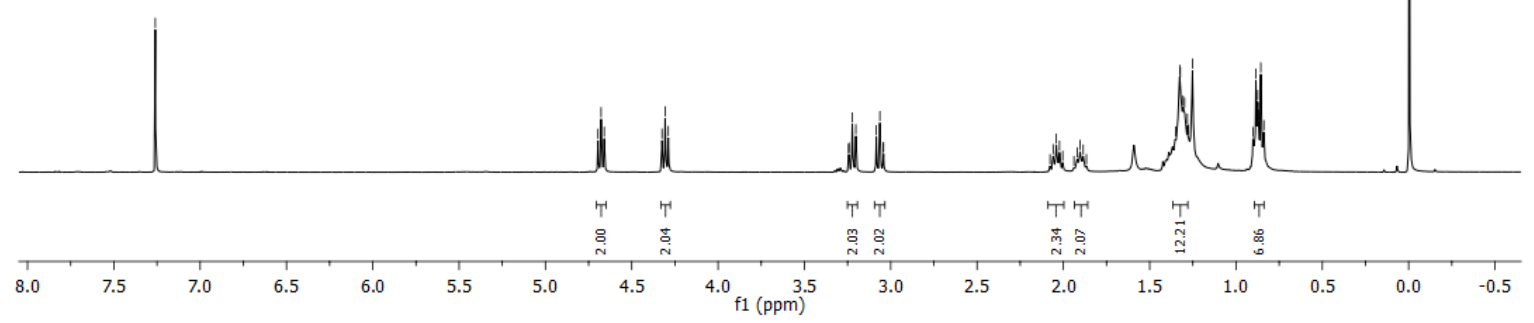

${ }^{1} \mathrm{H}$ NMR (400 MHz) spectrum of $\mathbf{4 f}$ in $\mathrm{CDCl}_{3}$



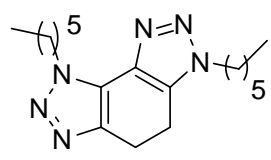

$4 f$

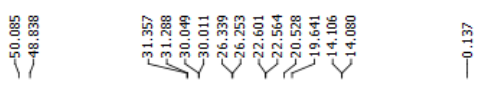

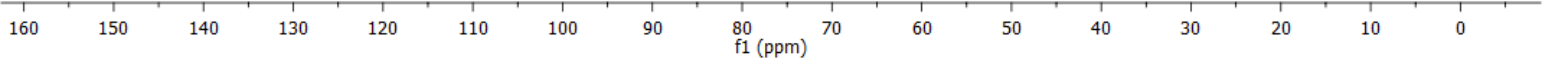

${ }^{13} \mathrm{C}\left\{{ }^{1} \mathrm{H}\right\}$ NMR (101 MHz) spectrum of $\mathbf{4} \mathbf{f}$ in $\mathrm{CDCl}_{3}$ 


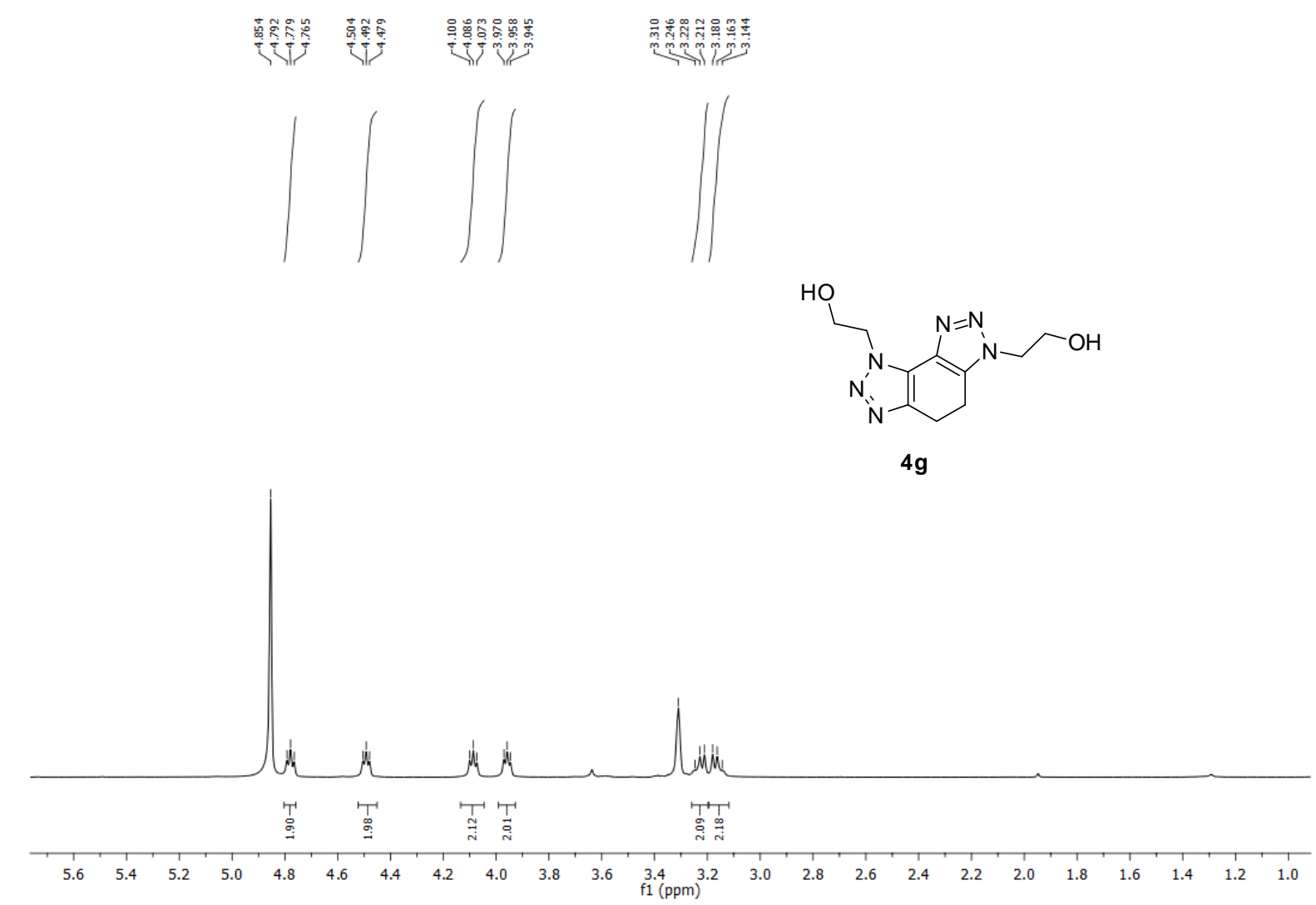

${ }^{1} \mathrm{H}$ NMR $(400 \mathrm{MHz})$ spectrum of $\mathbf{4 g}$ in $\mathrm{CD}_{3} \mathrm{OD}$

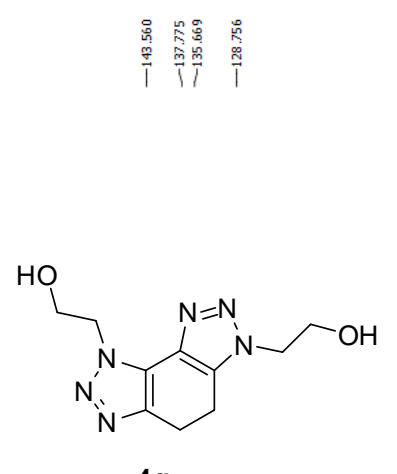

$\mathbf{4 g}$

\begin{tabular}{rllllllllllllllllllllllllllll}
\hline & 220 & 210 & 200 & 190 & 180 & 170 & 160 & 150 & 140 & 130 & 120 & 110 & 100 & 90 & 80 & 70 & 60 & 50 & 40 & 30 & 20 & 10 & 0 & -10
\end{tabular}

${ }^{13} \mathrm{C}\left\{{ }^{1} \mathrm{H}\right\} \mathrm{NMR}(101 \mathrm{MHz})$ spectrum of $\mathbf{4 g}$ in $\mathrm{CD}_{3} \mathrm{OD}$ 


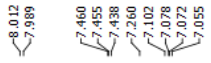

4h

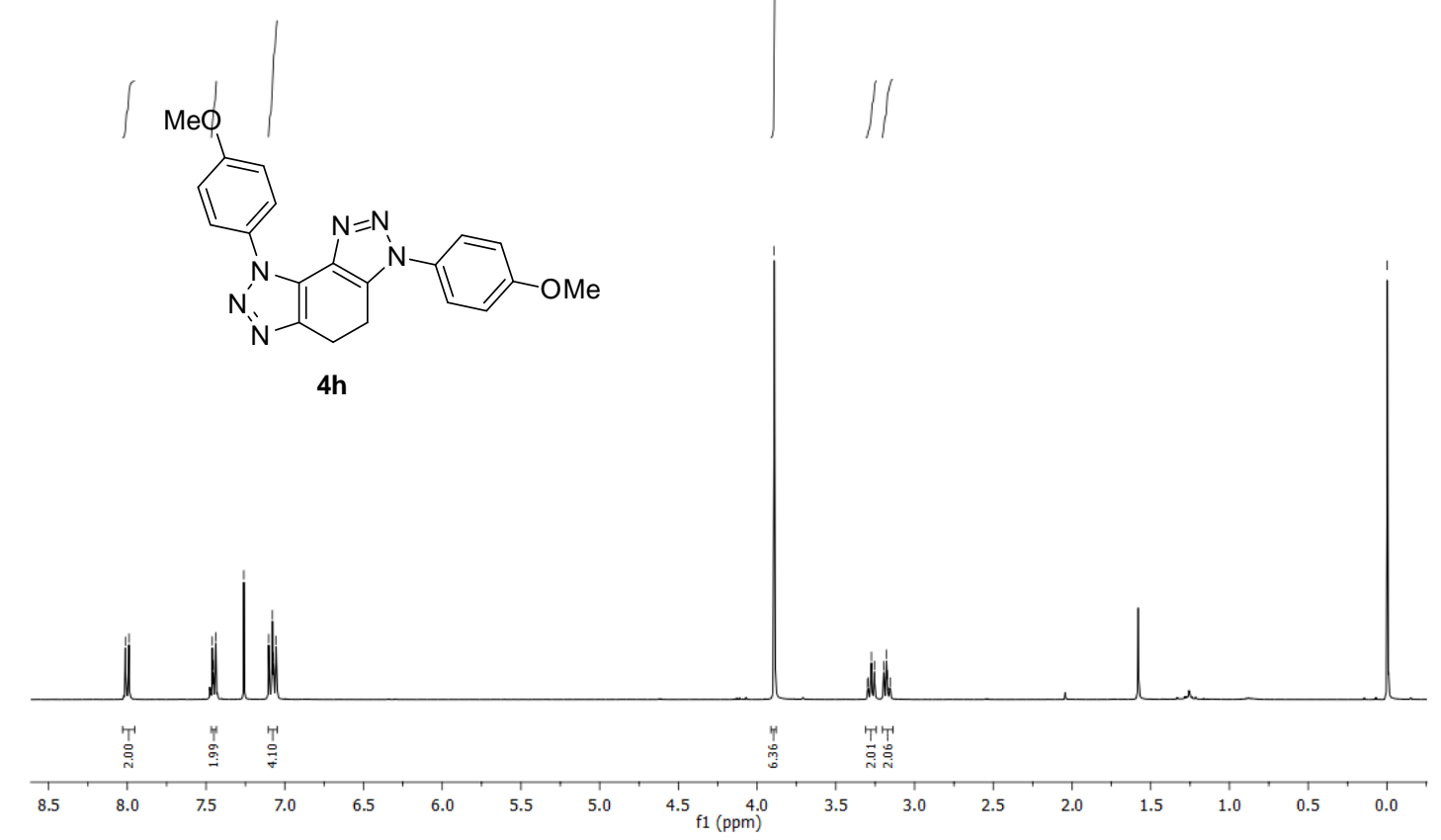

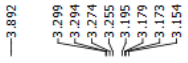

${ }^{1} \mathrm{H}$ NMR $(400 \mathrm{MHz})$ spectrum of $4 \mathrm{~h}$ in $\mathrm{CDCl}_{3}$

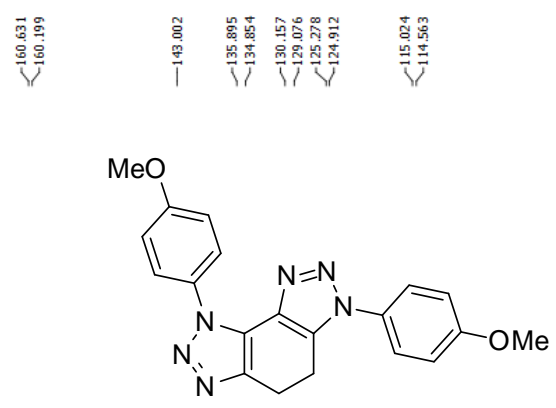

4h

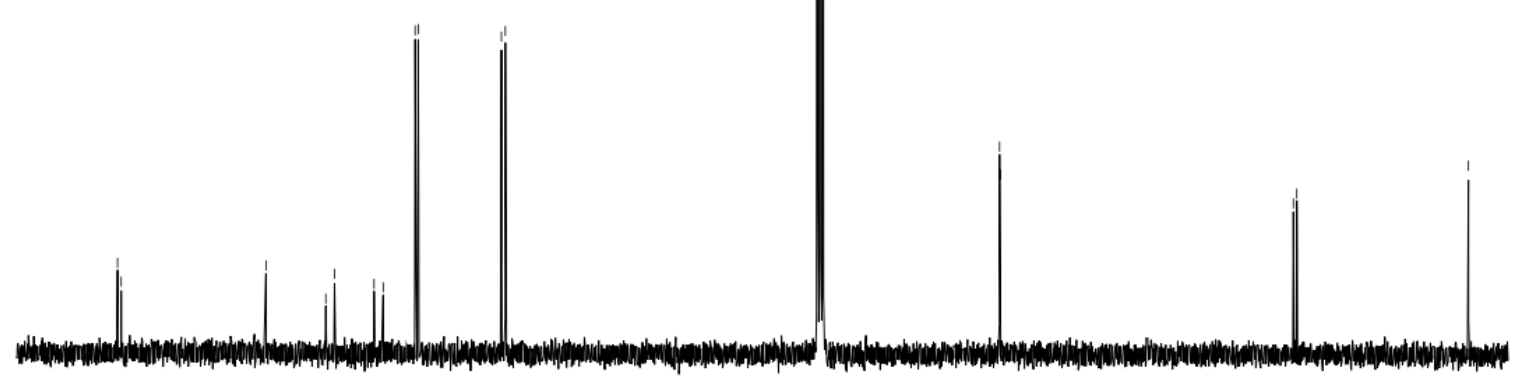

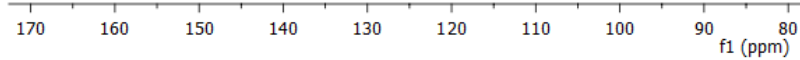

${ }^{13} \mathrm{C}\left\{{ }^{1} \mathrm{H}\right\}$ NMR (101 MHz) spectrum of $\mathbf{4 h}$ in $\mathrm{CDCl}_{3}$ 


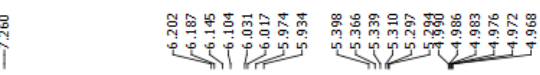

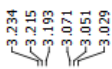
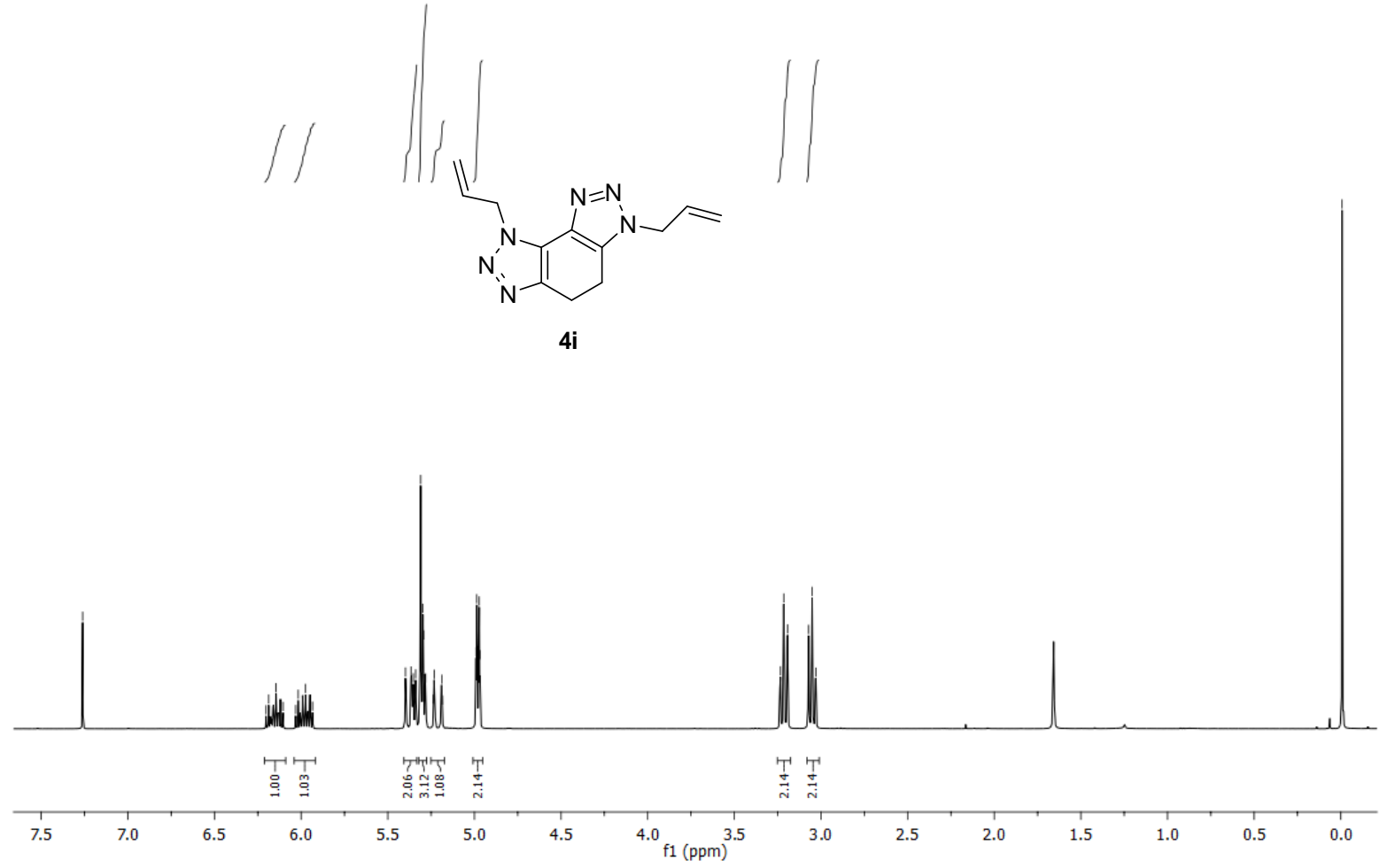

${ }^{1} \mathrm{H}$ NMR (400 MHz) spectrum of $4 \mathbf{i}$ in $\mathrm{CDCl}_{3}$
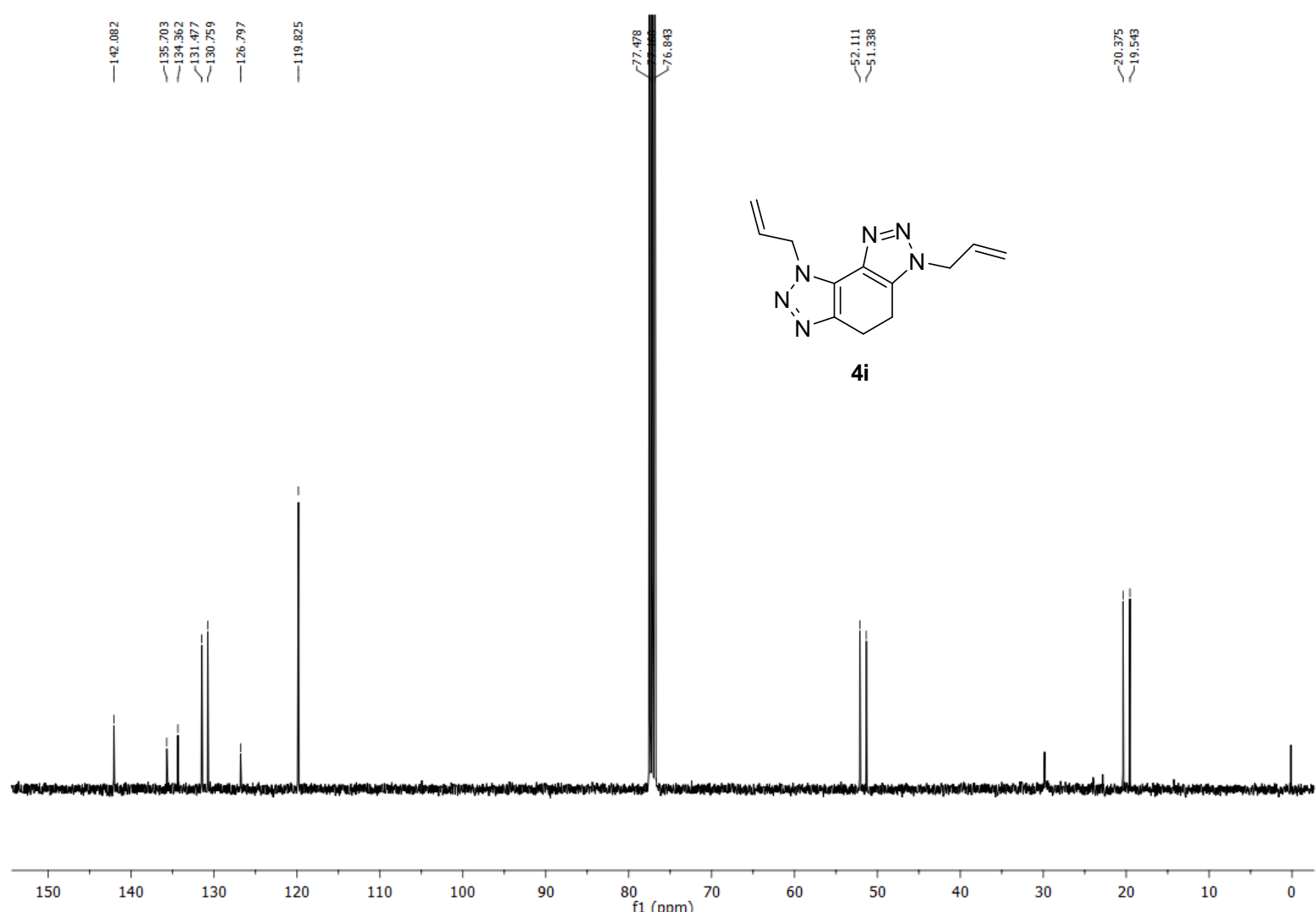

${ }^{13} \mathrm{C}\left\{{ }^{1} \mathrm{H}\right\}$ NMR (101 MHz) spectrum of $4 \mathbf{i}$ in $\mathrm{CDCl}_{3}$ 


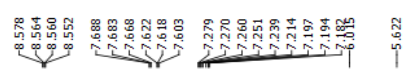

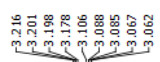
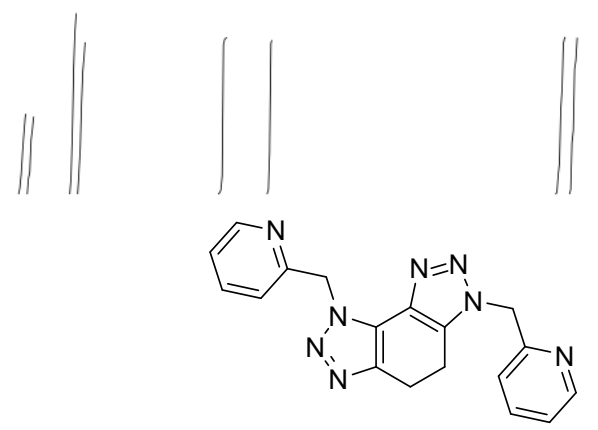

$4 \mathbf{j}$

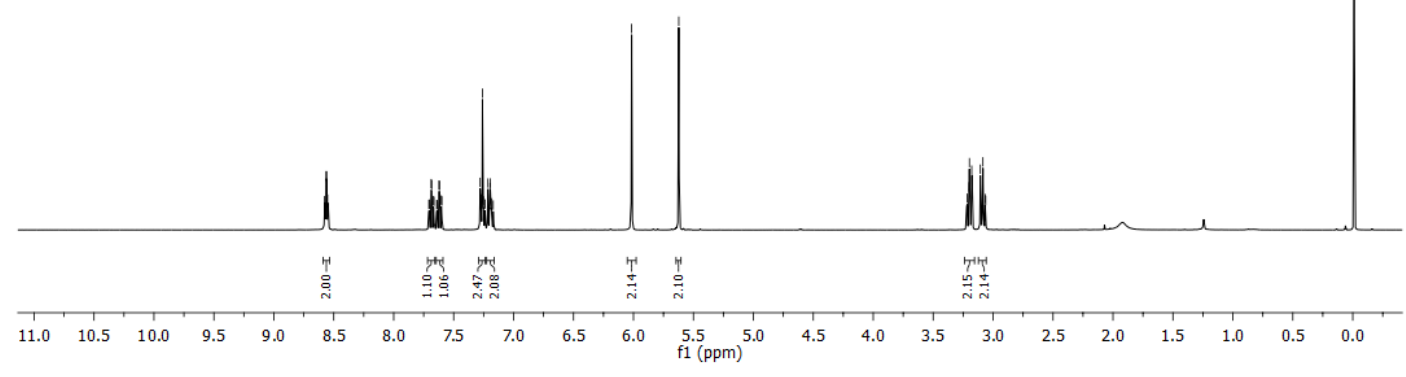

${ }^{1} \mathrm{H}$ NMR (400 MHz) spectrum of $4 \mathbf{j}$ in $\mathrm{CDCl}_{3}$

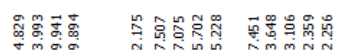



(2)

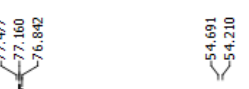

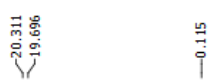

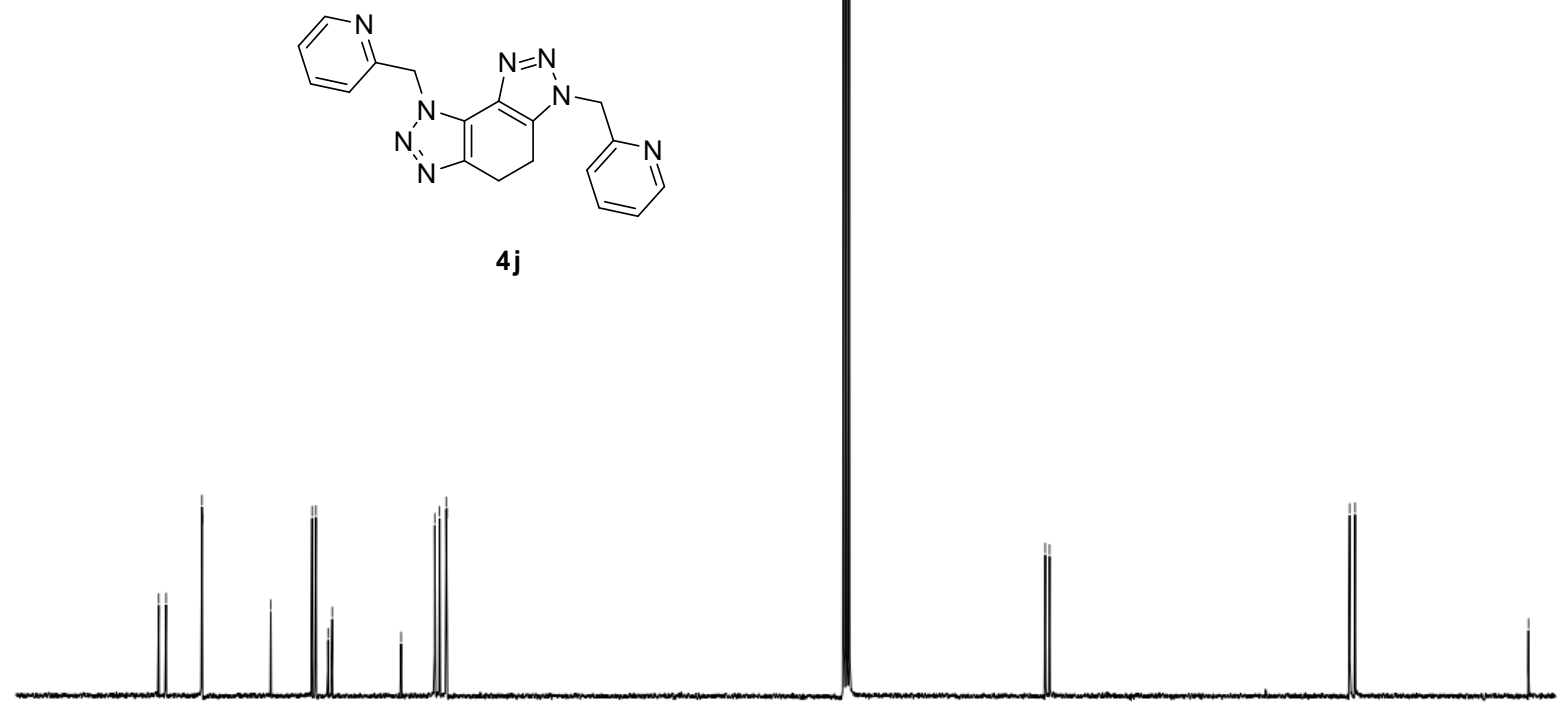

$4 \mathbf{j}$
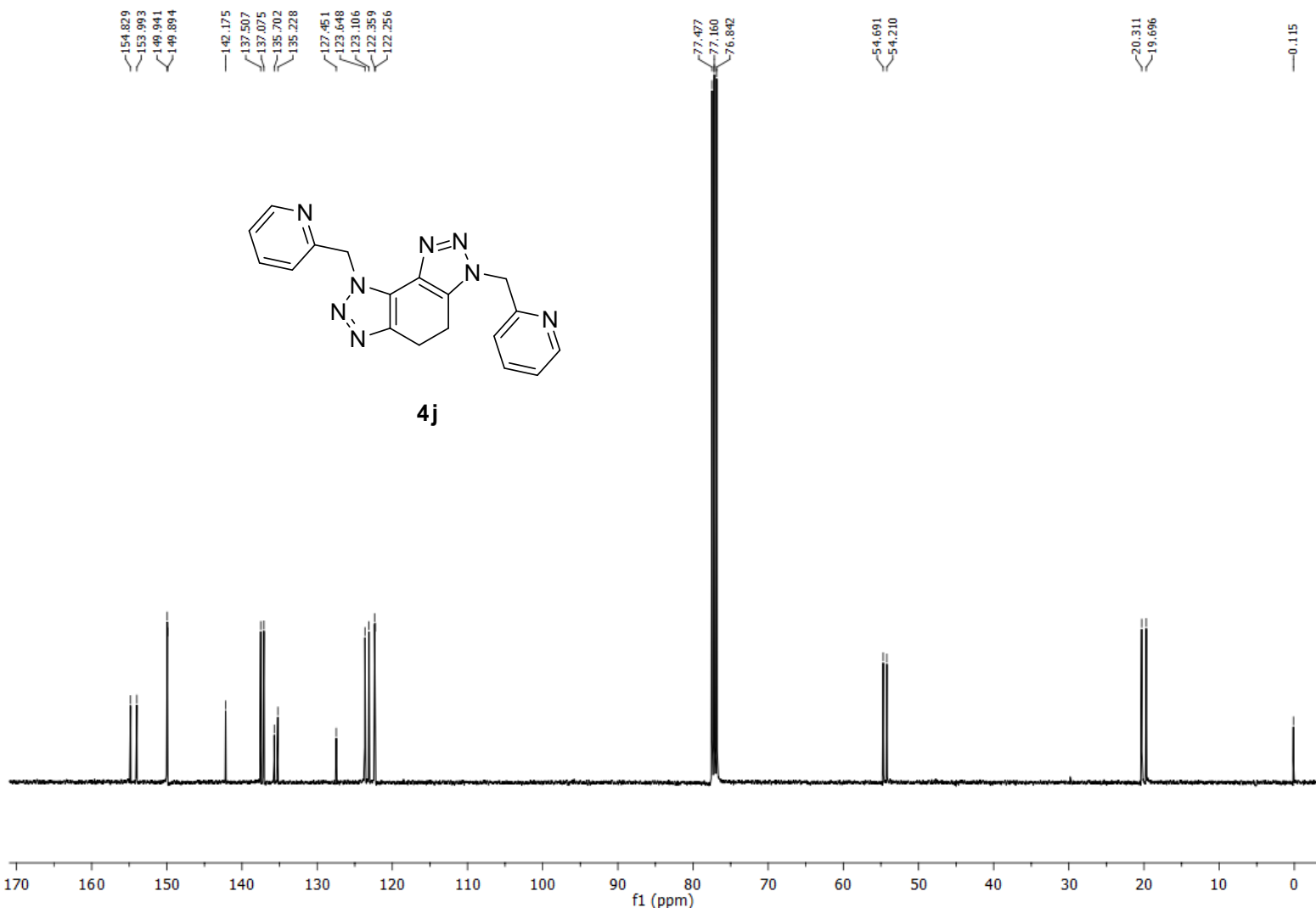

${ }^{13} \mathrm{C}\left\{{ }^{1} \mathrm{H}\right\}$ NMR (101 MHz) spectrum of $4 \mathrm{j}$ in $\mathrm{CDCl}_{3}$ 


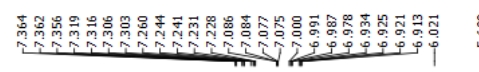


$4 k$

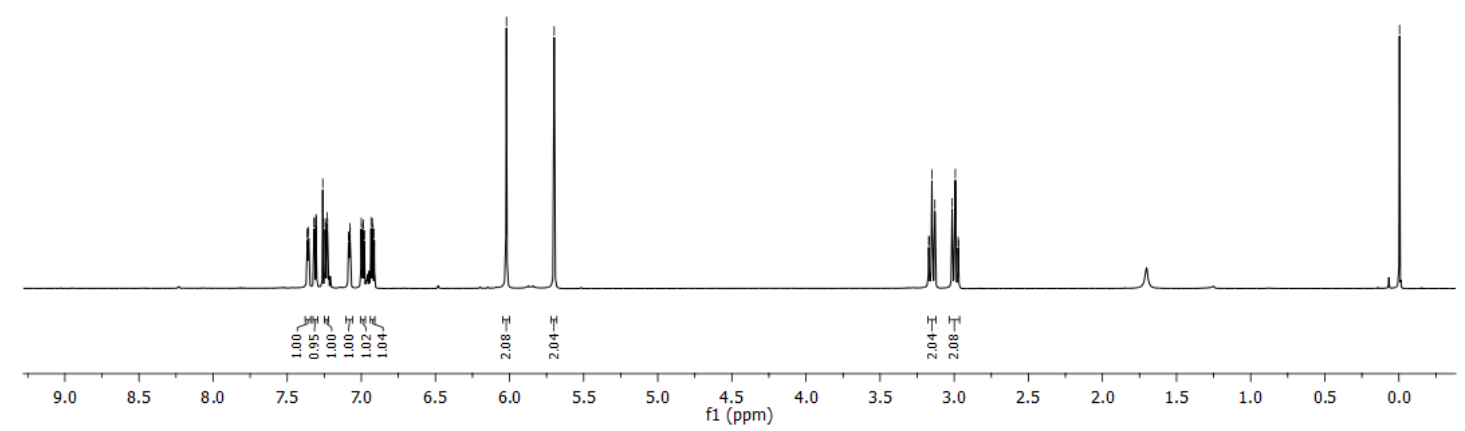

${ }^{1} \mathrm{H} \mathrm{NMR} \mathrm{(400} \mathrm{MHz)} \mathrm{spectrum} \mathrm{of} \mathbf{4} \mathbf{k}$ in $\mathrm{CDCl}_{3}$

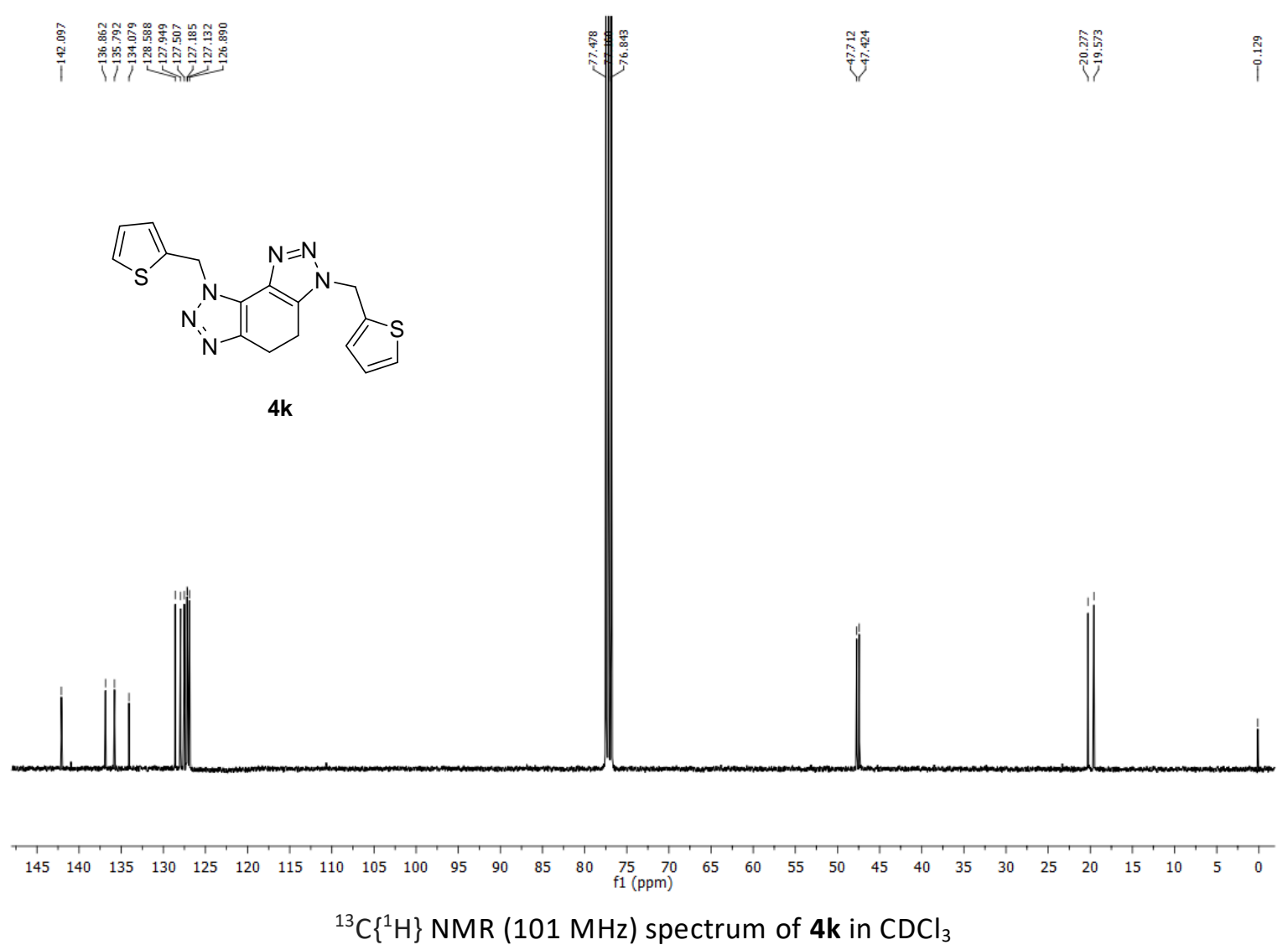






${ }^{1} \mathrm{H}$ NMR (400 MHz) spectrum of $4 \mathrm{l}$ in $\mathrm{CDCl}_{3}$

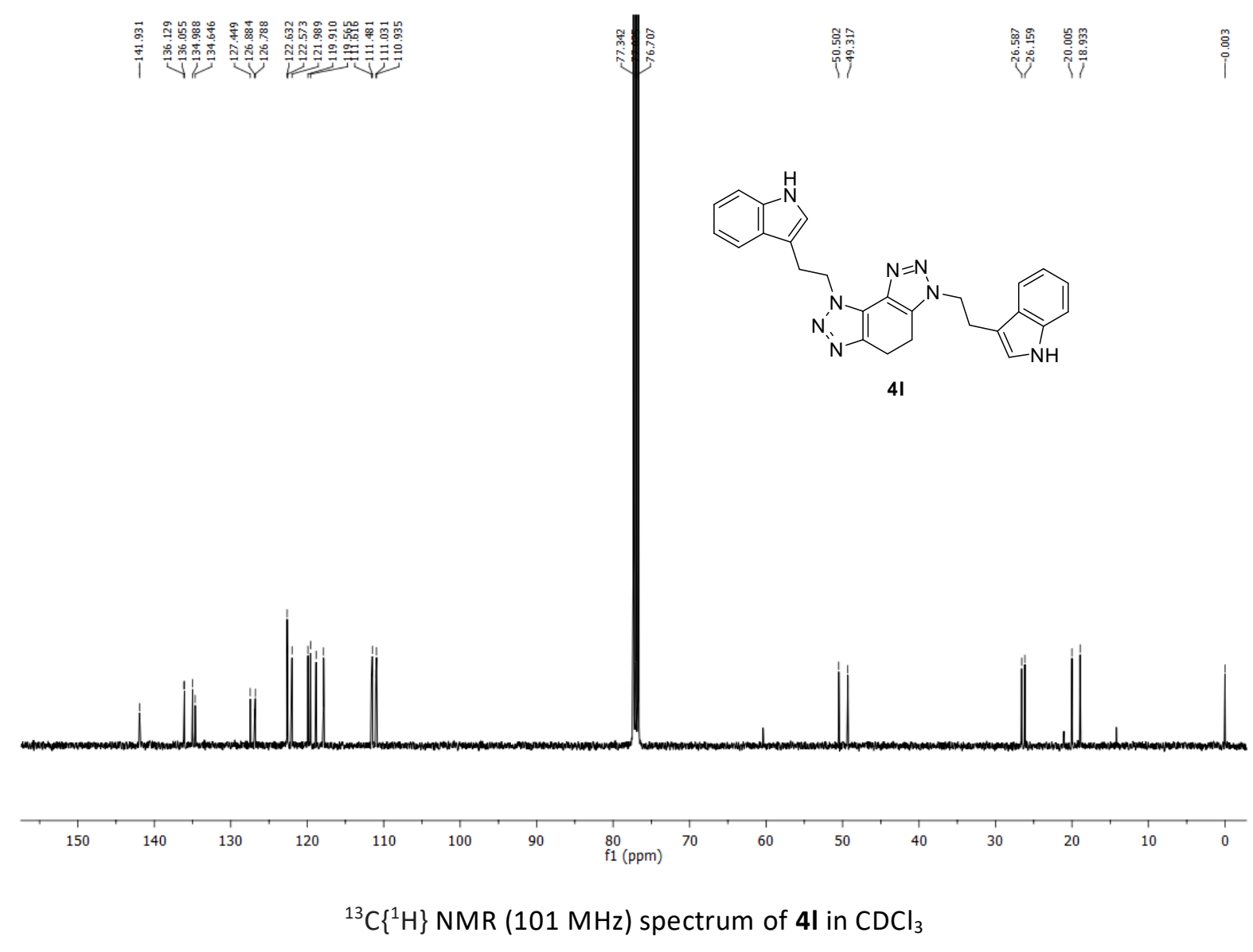




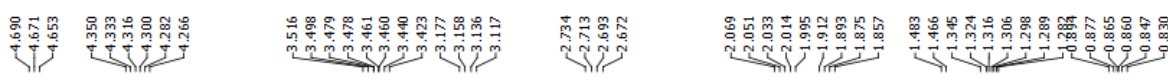
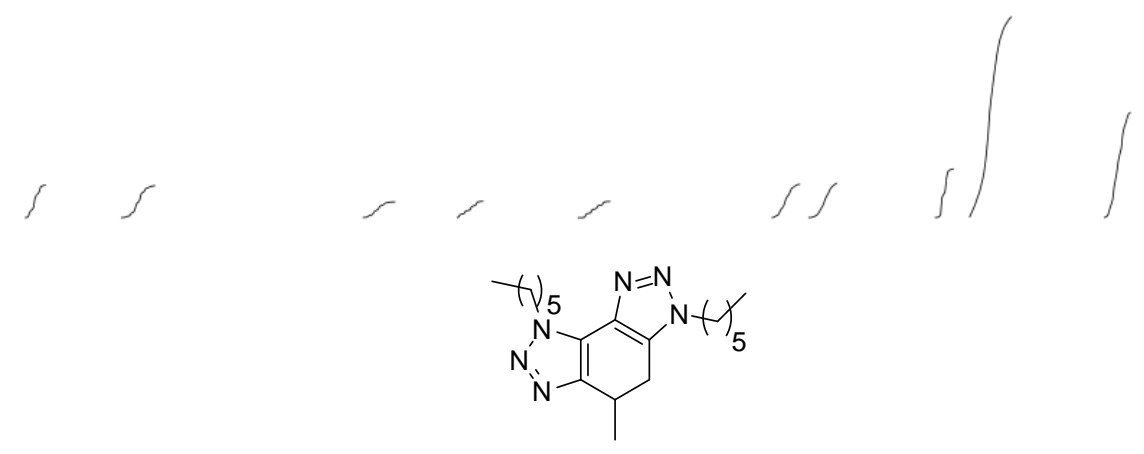

$4 m$

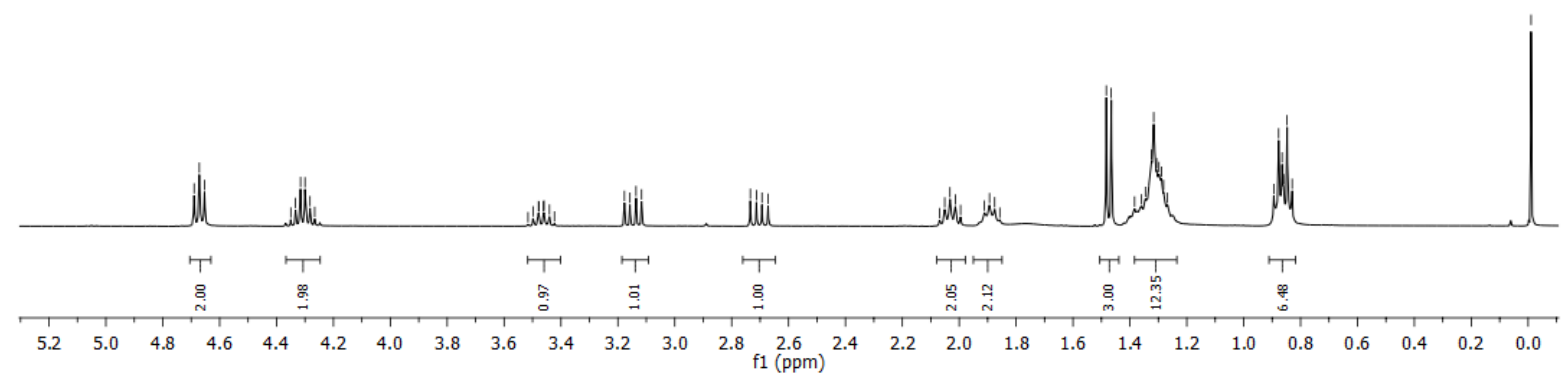

${ }^{1} \mathrm{H}$ NMR (400 MHz) spectrum of $4 \mathrm{~m}$ in $\mathrm{CDCl}_{3}$
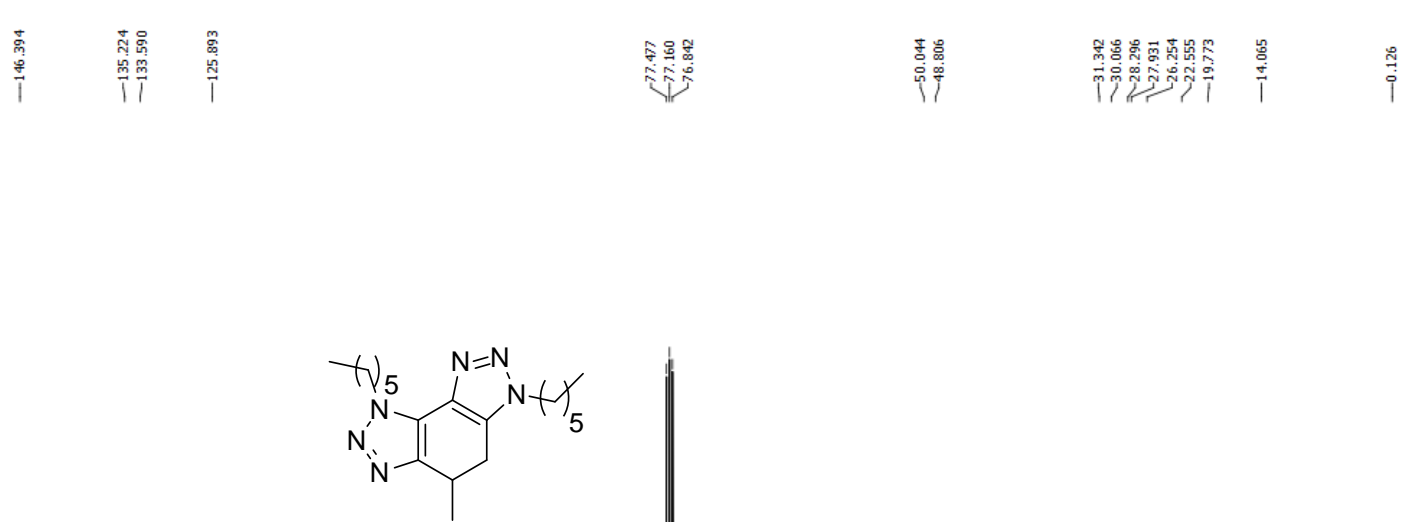

$4 \mathrm{~m}$
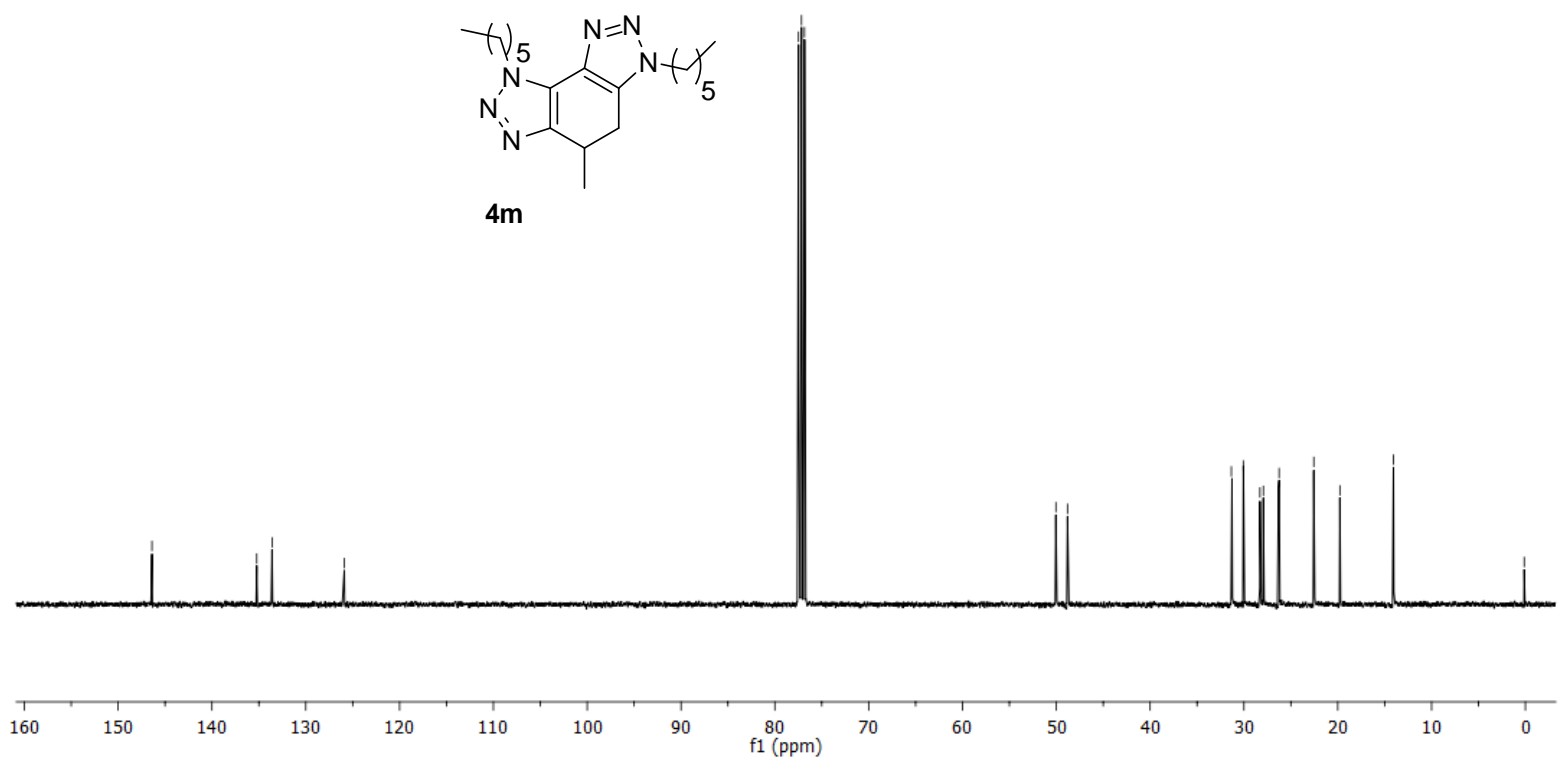

${ }^{13} \mathrm{C}\left\{{ }^{1} \mathrm{H}\right\}$ NMR (101 MHz) spectrum of $4 \mathrm{~m}$ in $\mathrm{CDCl}_{3}$ 


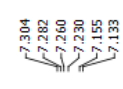

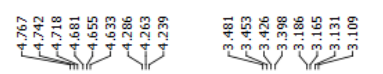

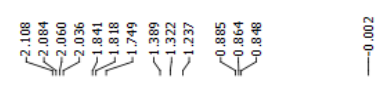



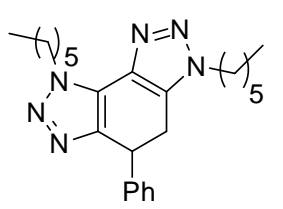

$4 n$



${ }^{1} \mathrm{H}$ NMR (300 MHz) spectrum of $4 n$ in $\mathrm{CDCl}_{3}$

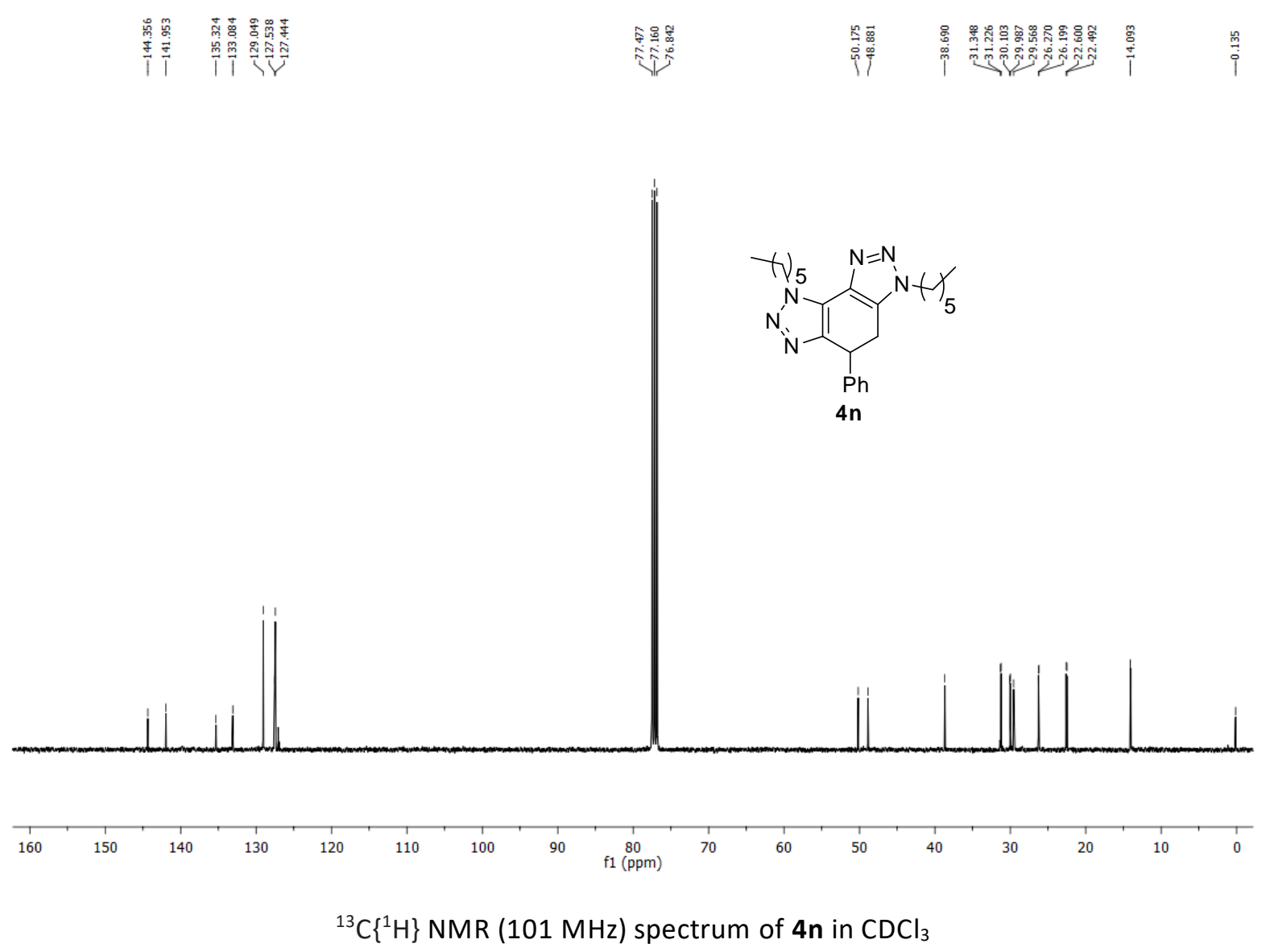




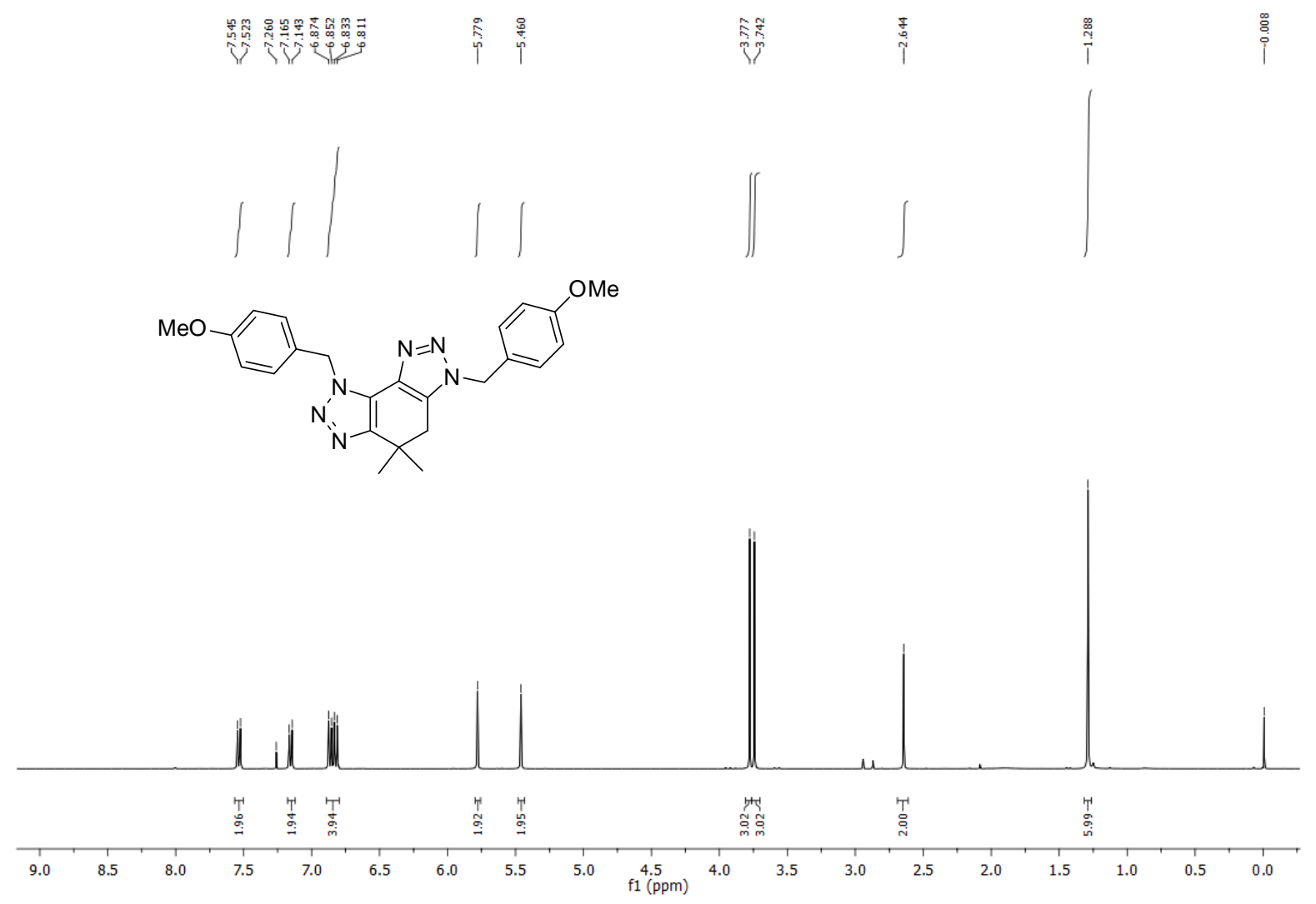

${ }^{1} \mathrm{H} N M R(400 \mathrm{MHz})$ spectrum of 40 in $\mathrm{CDCl}_{3}$

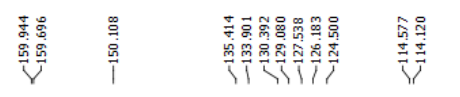

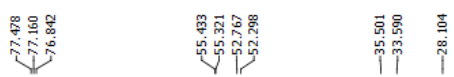<smiles>COc1ccc(Cn2nnc3c2CC(C)(C)c2c-3nnn2Cc2ccc(OC)cc2)cc1</smiles>

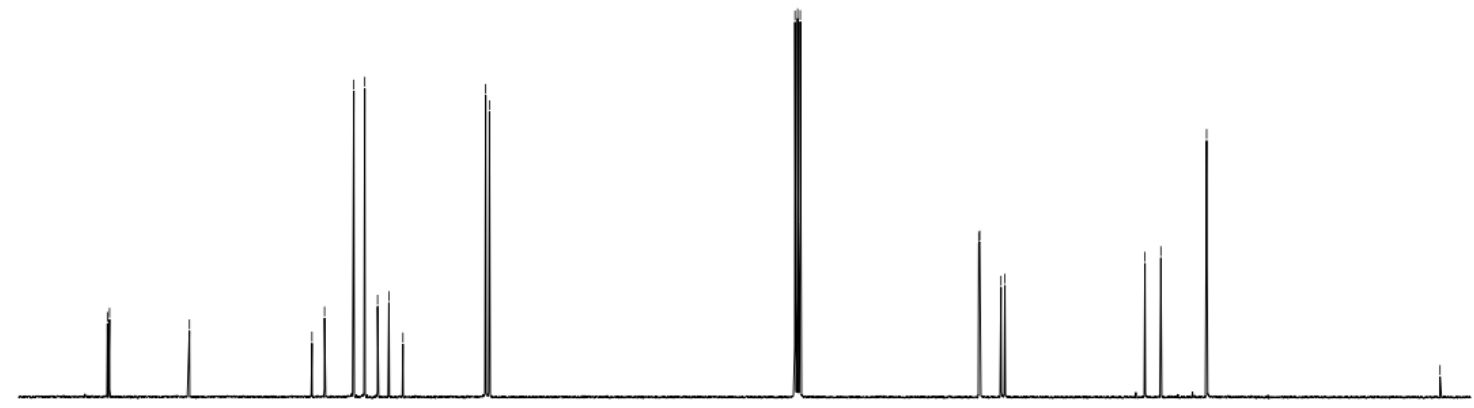

$\begin{array}{rllllllllllllllllll}170 & 160 & 150 & 140 & 130 & 120 & 110 & 100 & 90 & \begin{array}{r}1 \\ \mathrm{f} 1(\mathrm{ppm})\end{array} & 70 & 60 & 50 & 40 & 30 & 20 & 10 & 0\end{array}$

${ }^{13} \mathrm{C}\left\{{ }^{1} \mathrm{H}\right\}$ NMR (101 MHz) spectrum of 40 in $\mathrm{CDCl}_{3}$ 


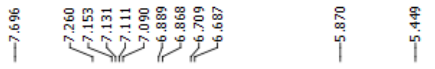

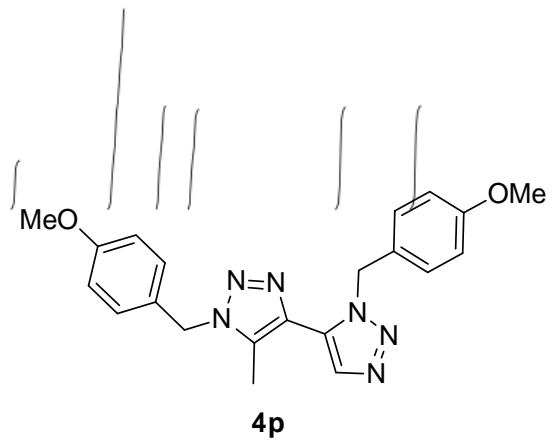

$4 p$

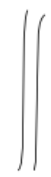

$$
1
$$

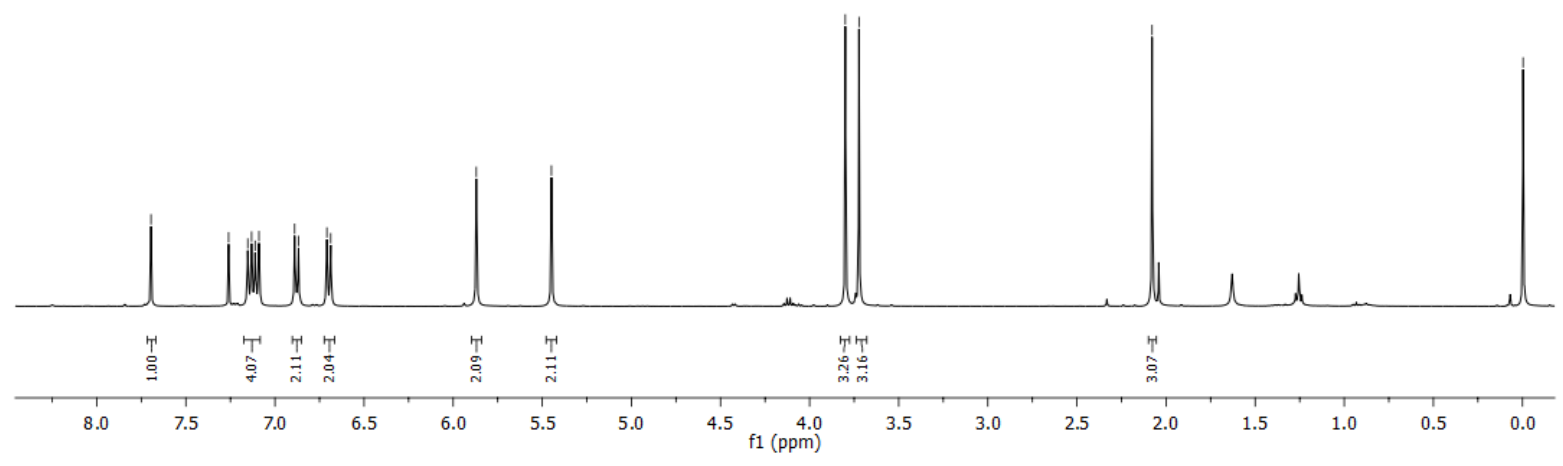

${ }^{1} \mathrm{H}$ NMR $\left(400 \mathrm{MHz}\right.$ ) spectrum of $4 \mathrm{p}$ in $\mathrm{CDCl}_{3}$

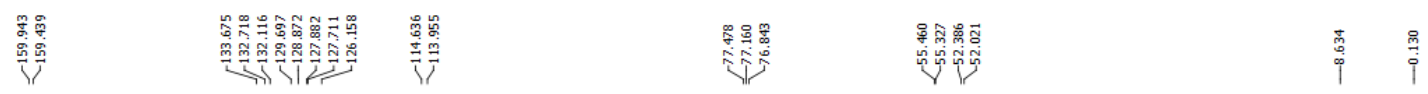
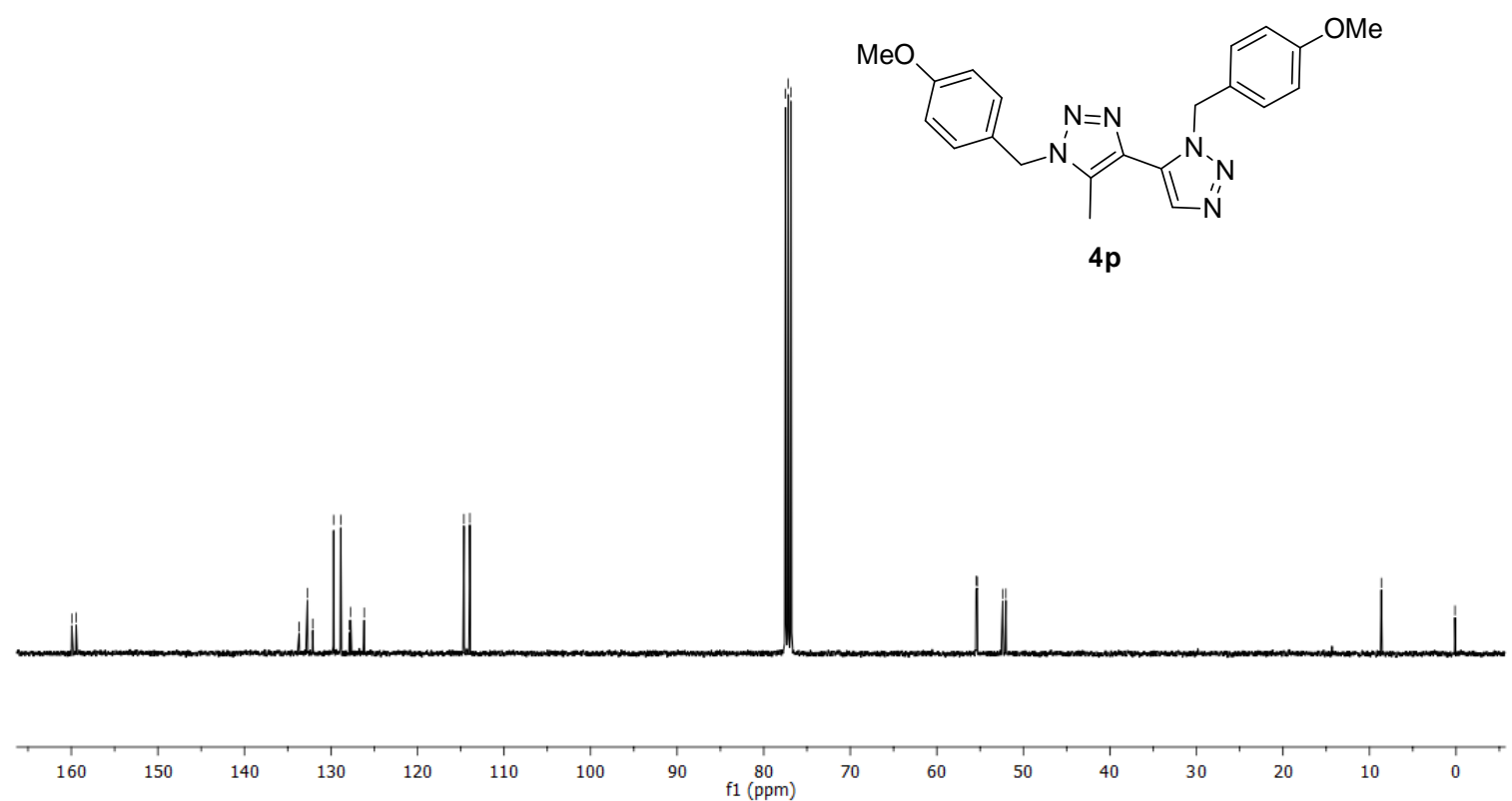

${ }^{13} \mathrm{C}\left\{{ }^{1} \mathrm{H}\right\}$ NMR (101 MHz) spectrum of $4 p$ in $\mathrm{CDCl}_{3}$ 


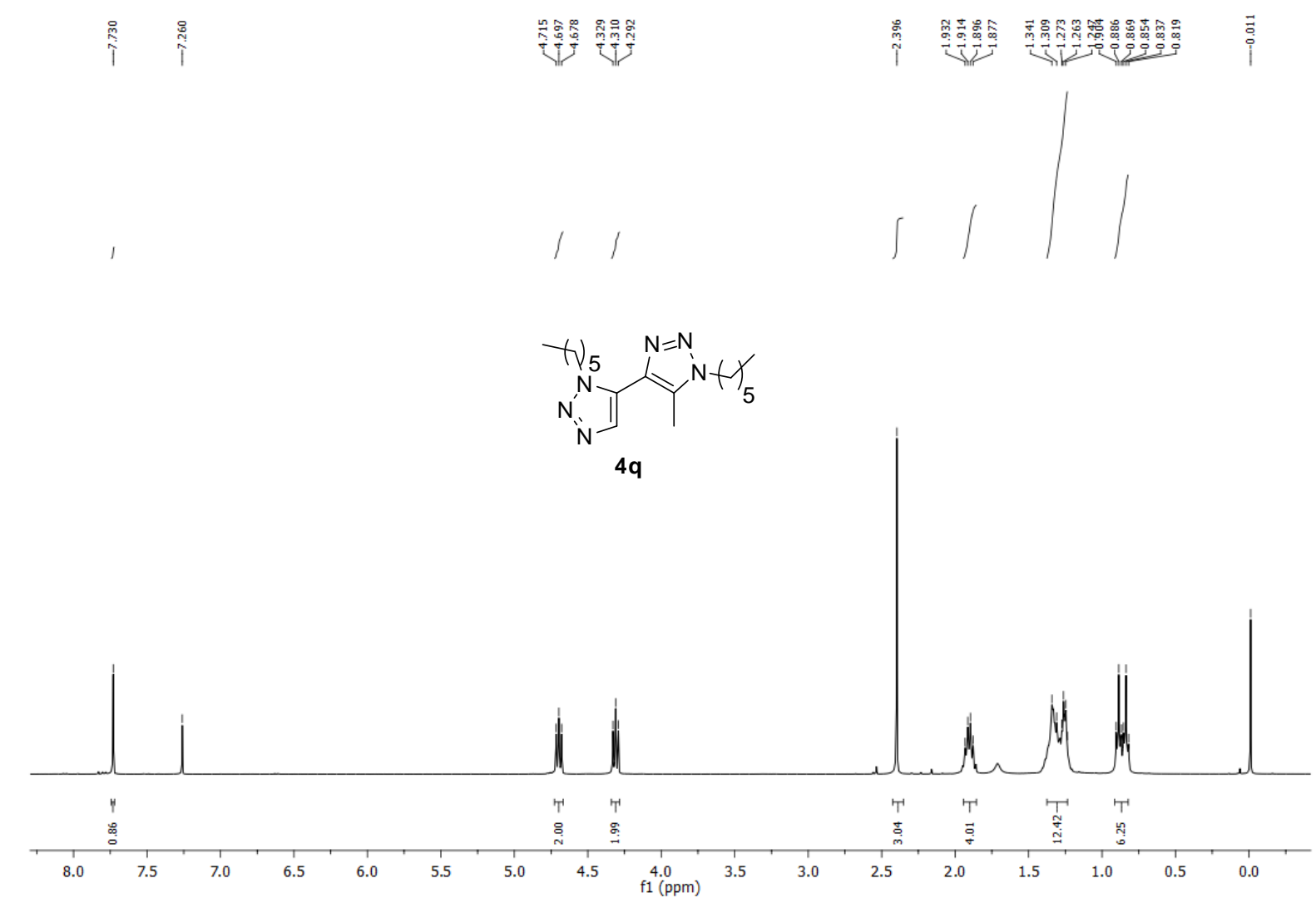

${ }^{1} \mathrm{H}$ NMR $\left(400 \mathrm{MHz}\right.$ ) spectrum of $4 \mathrm{p}$ in $\mathrm{CDCl}_{3}$

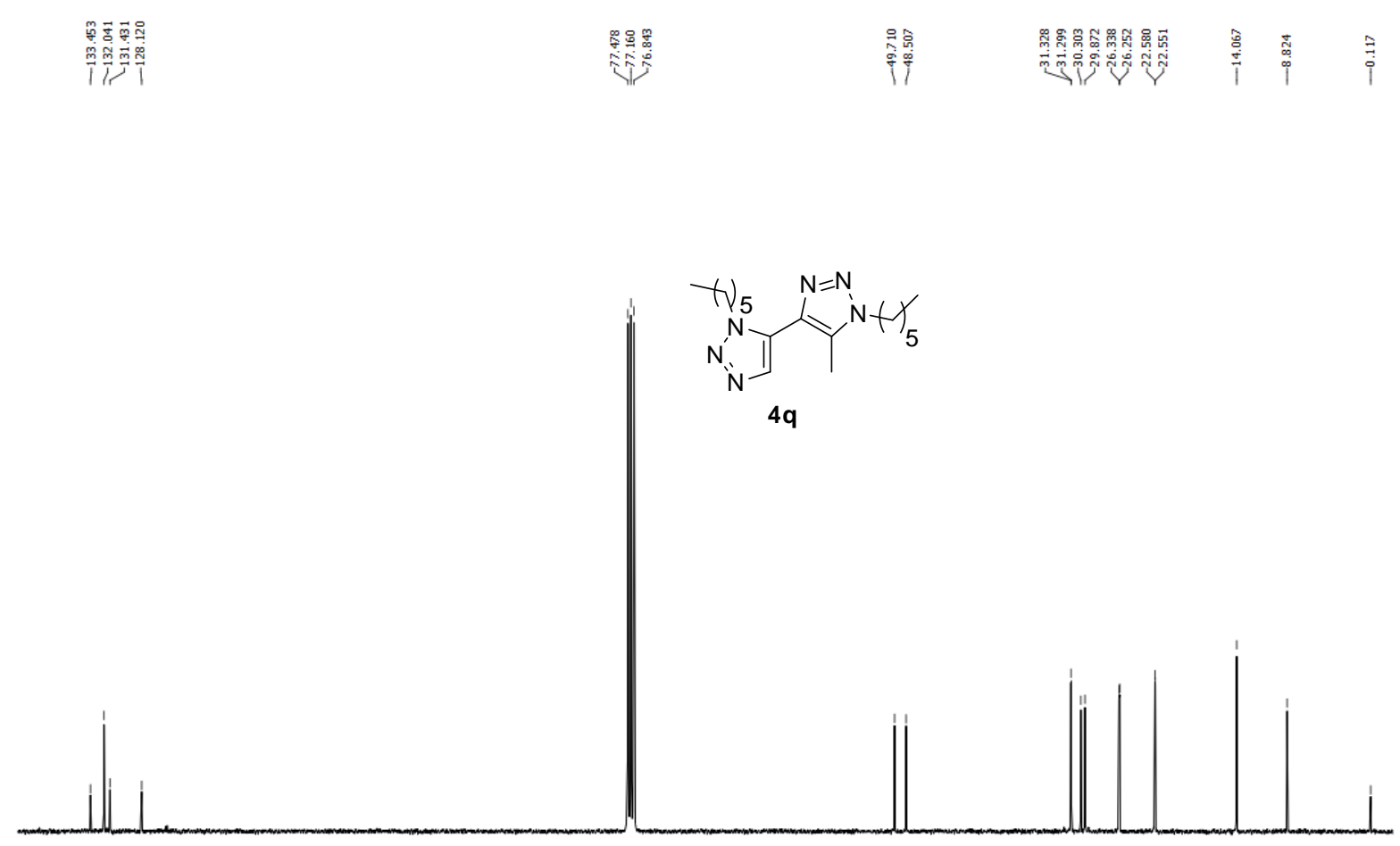

$\begin{array}{llllllllllllllllllllllllllllllllll}140 & 135 & 130 & 125 & 120 & 115 & 110 & 105 & 100 & 95 & 90 & 85 & 80 & 75 & 70 & 65 & 60 & 55 & 50 & 45 & 40 & 35 & 30 & 25 & 20 & 15 & 10 & 5 & 0\end{array}$

${ }^{13} \mathrm{C}\left\{{ }^{1} \mathrm{H}\right\}$ NMR $\left(101 \mathrm{MHz}\right.$ ) spectrum of $\mathbf{4 q}$ in $\mathrm{CDCl}_{3}$ 

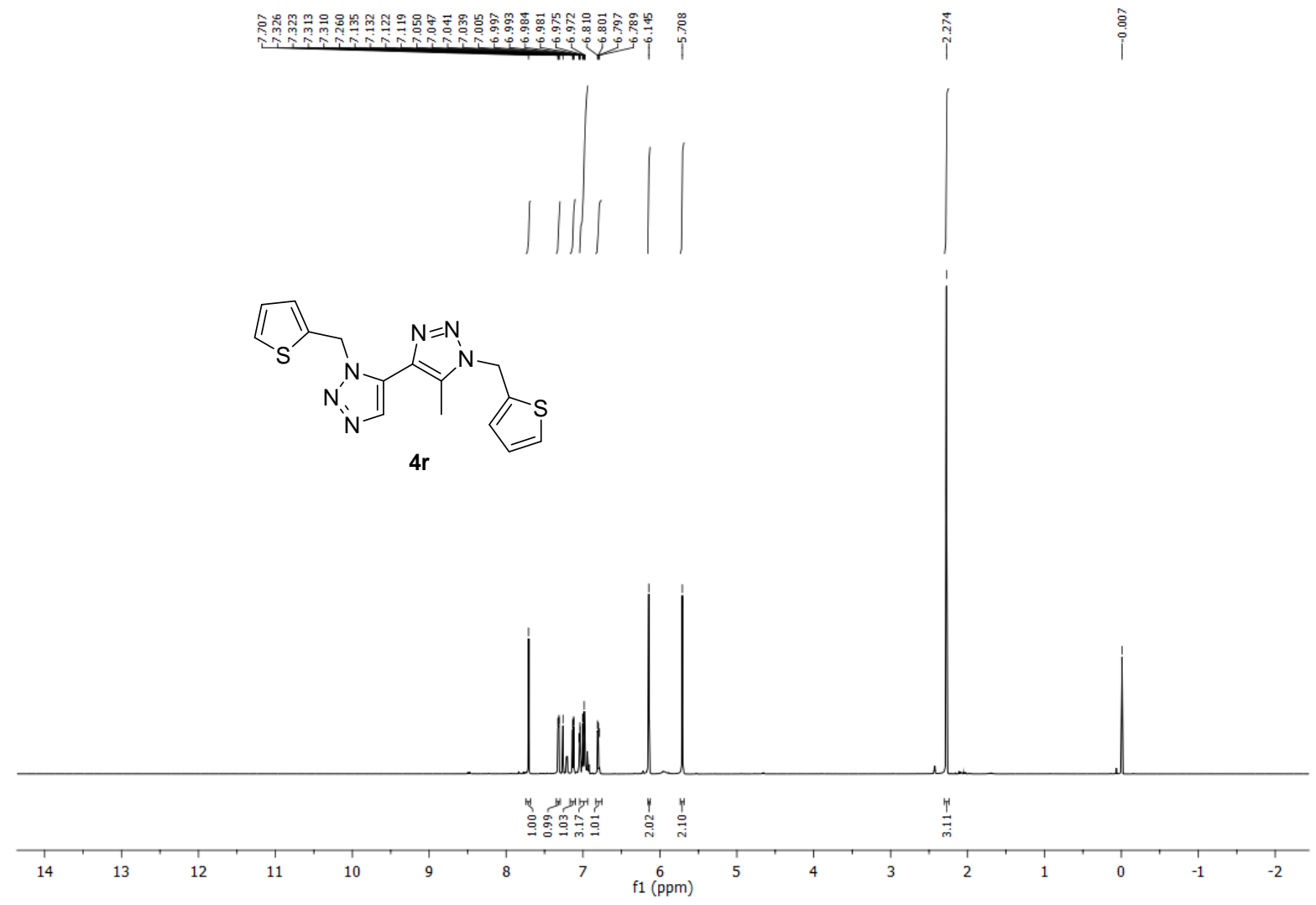

${ }^{1} \mathrm{H}$ NMR (400 MHz) spectrum of $\mathbf{4 r}$ in $\mathrm{CDCl}_{3}$

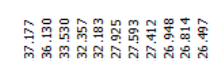

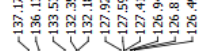

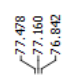

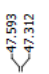


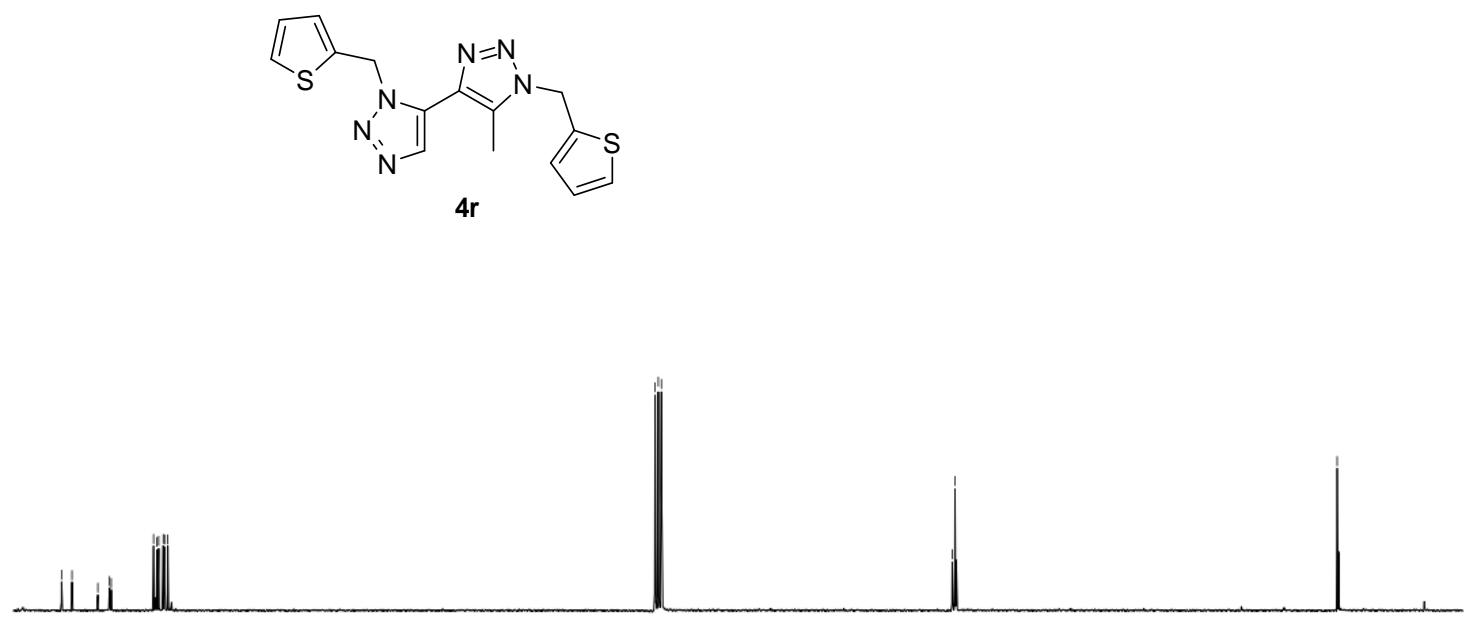

$\begin{array}{llllllllllllllllllllllllllllllll}140 & 135 & 130 & 125 & 120 & 115 & 110 & 105 & 100 & 95 & 90 & 85 & 80 & 75 & 70 & 65 & 60 & 55 & 50 & 45 & 40 & 35 & 30 & 25 & 20 & 15 & 10 & 5 & 0\end{array}$

${ }^{13} \mathrm{C}\left\{{ }^{1} \mathrm{H}\right\}$ NMR (101 MHz) spectrum of $\mathbf{4} \mathbf{r}$ in $\mathrm{CDCl}_{3}$ 


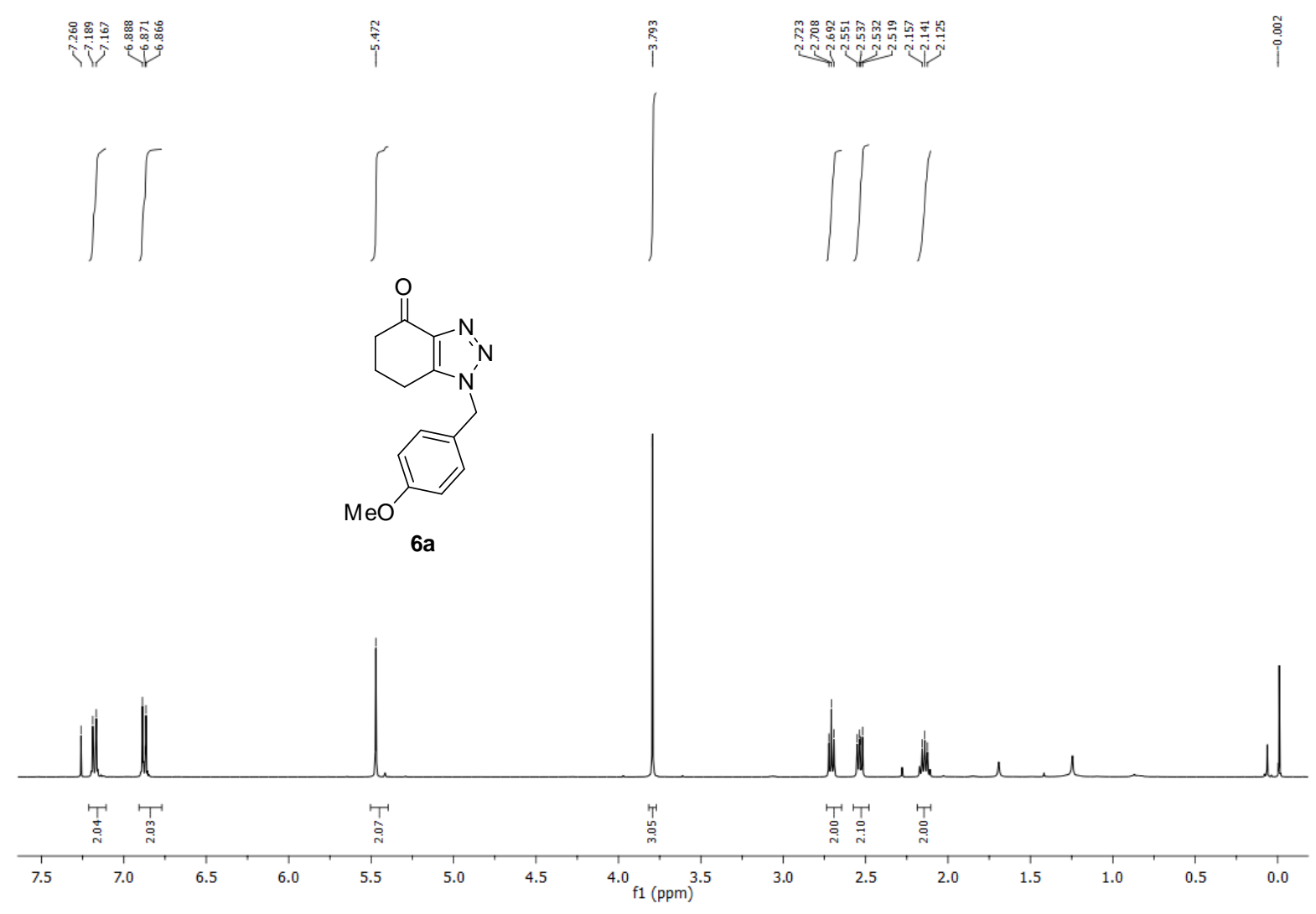

${ }^{1} \mathrm{H}$ NMR (400 MHz) spectrum of 6 a in $\mathrm{CDCl}_{3}$

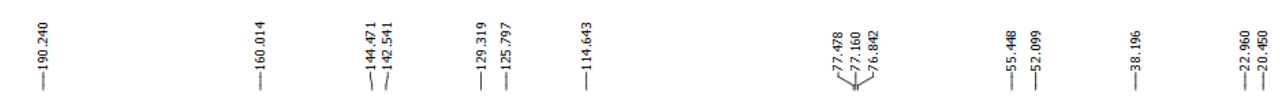

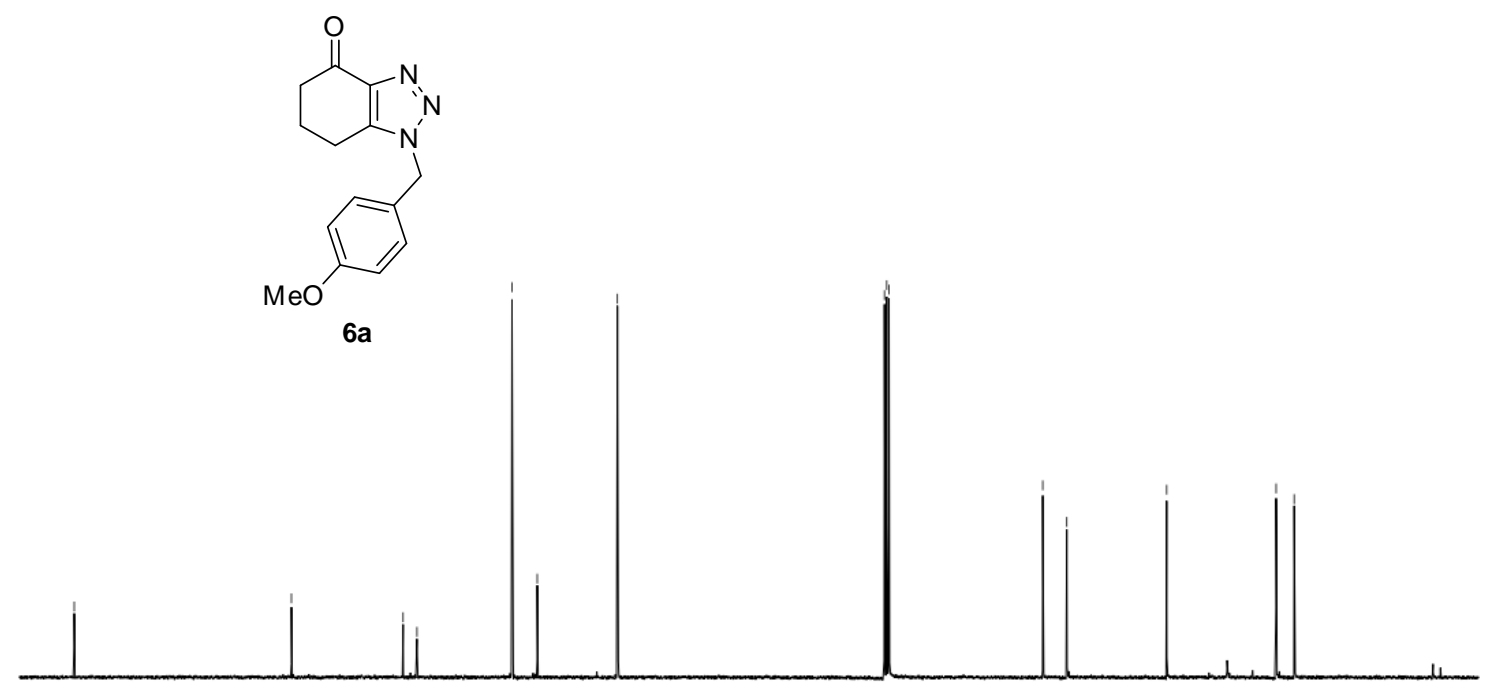

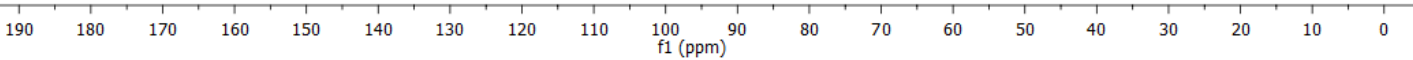

${ }^{13} \mathrm{C}\left\{{ }^{1} \mathrm{H}\right\} \mathrm{NMR}(101 \mathrm{MHz})$ spectrum of $6 \mathrm{a}$ in $\mathrm{CDCl}_{3}$ 


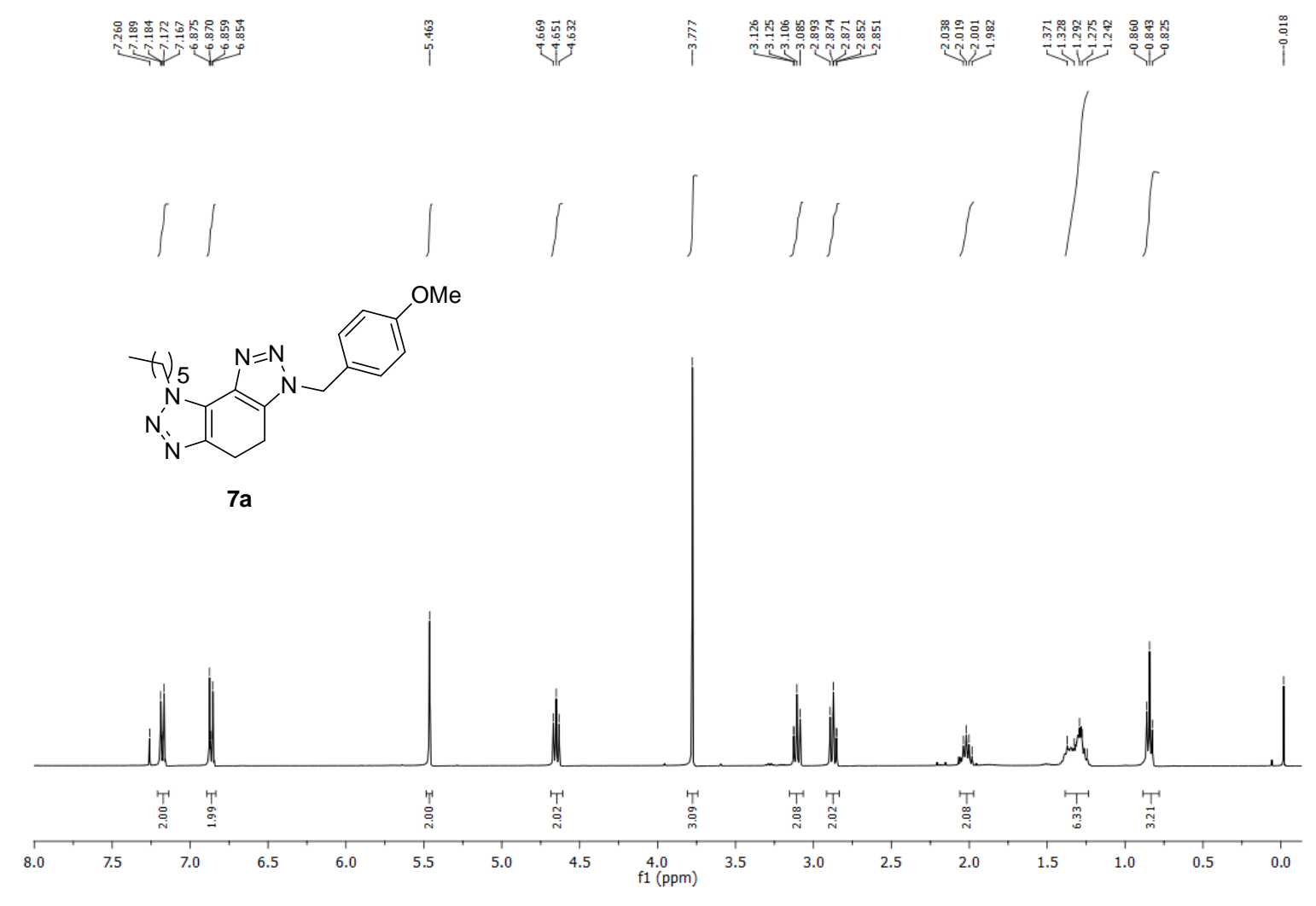

${ }^{1} \mathrm{H} \mathrm{NMR}(400 \mathrm{MHz})$ spectrum of $7 \mathrm{a}$ in $\mathrm{CDCl}_{3}$






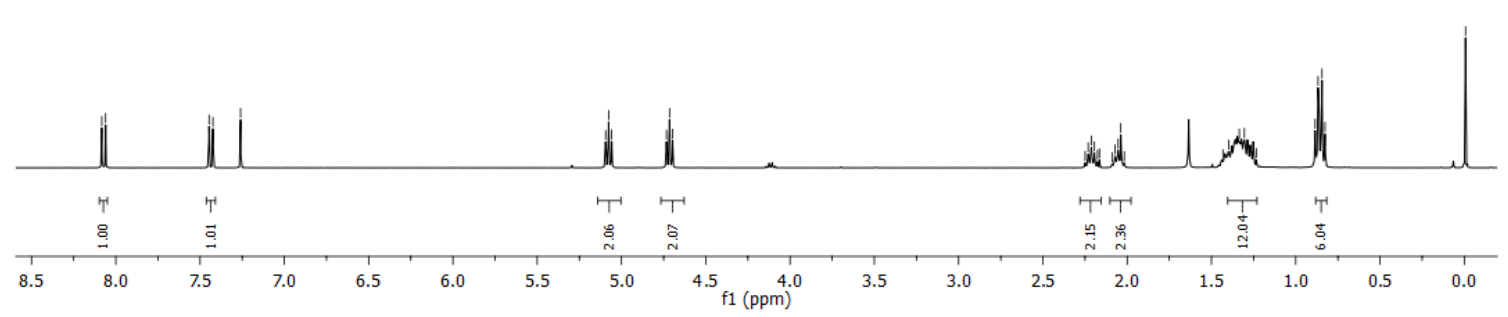

${ }^{1} \mathrm{H}$ NMR $(400 \mathrm{MHz})$ spectrum of $8 \mathbf{a}$ in $\mathrm{CDCl}_{3}$

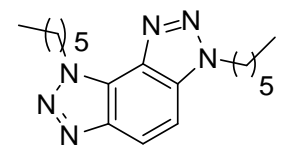

$8 a$

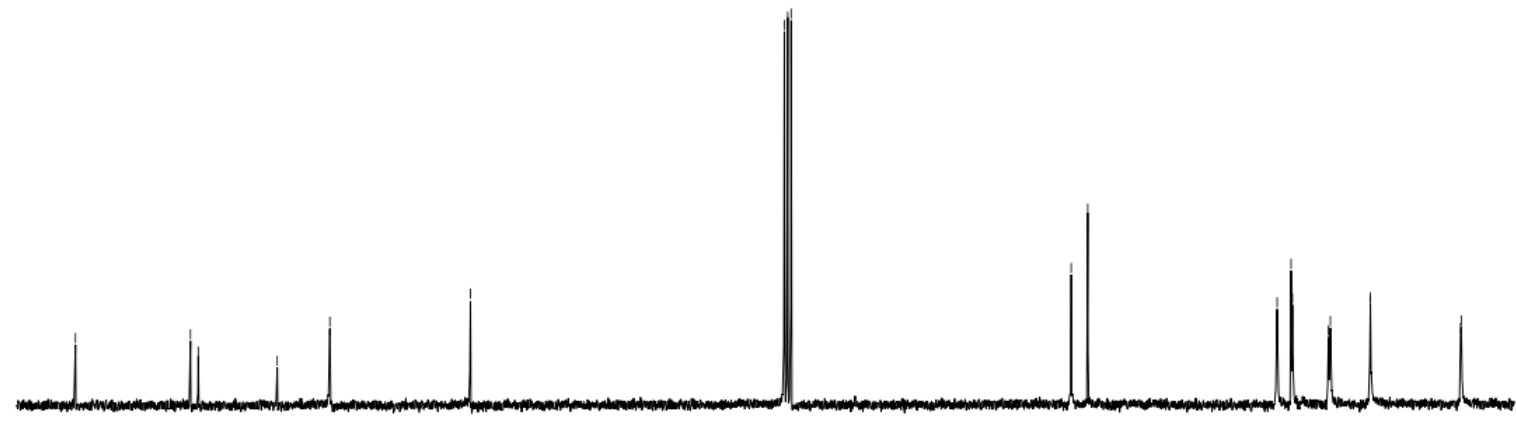

$\begin{array}{llllllllllllllllllllllllllllll}145 & 140 & 135 & 130 & 125 & 120 & 115 & 110 & 105 & 100 & 95 & 90 & 85 & 80 & 75 & 70 & 65 & 60 & 55 & 50 & 45 & 40 & 35 & 30 & 25 & 20 & 15 & 10\end{array}$

${ }^{13} \mathrm{C}\left\{{ }^{1} \mathrm{H}\right\}$ NMR $(101 \mathrm{MHz})$ spectrum of $8 \mathrm{a}$ in $\mathrm{CDCl}_{3}$ 